\title{
Can Andean potatoes be agronomically biofortified with iron and zinc fertilizers?
}

\author{
Peter Kromann • Franklin Valverde • Soraya Alvarado • Rodrigo Vélez • José Pisuña • \\ Byron Potosí • Arturo Taipe • David Caballero • Amalia Cabezas • André Devaux
}

Received: 11 March 2016 / Accepted: 16 September 2016 /Published online: 28 September 2016

(C) The Author(s) 2016. This article is published with open access at Springerlink.com

\begin{abstract}
Aims The aim of this study was to investigate the proofof-concept that Andean potato (Solanum tuberosum L., Andigenum Group) can be agronomically biofortified with iron $(\mathrm{Fe})$ and zinc $(\mathrm{Zn})$ fertilizers.

Methods Greenhouse and field experiments were conducted in the Ecuadorian Andes with varying rates of foliar and soil applied $\mathrm{Fe}$ and $\mathrm{Zn}$ fertilizers to investigate the potential resulting increase in tuber Fe and tuber $\mathrm{Zn}$ concentrations.

Results The study showed that simple fertilizer practices enhancing $\mathrm{Zn}$ supply to potato plants can increase tuber $\mathrm{Zn}$ concentrations. The rate of increase of tuber $\mathrm{Zn}$ following $\mathrm{Zn}$ fertilization was similar across cultivars. A concomitant negative effect of high rates of $\mathrm{Zn}$ applications on yield was not seen, and a maximum $\mathrm{Zn}$ application level for increasing tuber $\mathrm{Zn}$ concentration was
\end{abstract}

Responsible Editor: Ismail Cakmak

Electronic supplementary material The online version of this article (doi:10.1007/s11104-016-3065-0) contains supplementary material, which is available to authorized users.

P. Kromann $(\bowtie) \cdot$ B. Potosí $\cdot$ A. Taipe $\cdot$ A. Devaux International Potato Center (CIP), P.O. Box 1719 21, Quito, Ecuador

e-mail: p.kromann@cgiar.org

F. Valverde $\cdot$ S. Alvarado $\cdot$ R. Vélez $\cdot$ J. Pisuña Instituto Nacional de Investigaciones Agropecuarias (INIAP), km 1 Panamericana Sur, Quito, Ecuador

D. Caballero · A. Cabezas

Escuela Superior Politécnica de Chimborazo (ESPOCH),

Riobamba, Ecuador not identified. A positive tuber yield effect was seen at one field site. High rates of foliar $\mathrm{Zn}$ application reached a 2.51-fold tuber $\mathrm{Zn}$ increase, and high rates of soil $\mathrm{Zn}$ application a 1.91-fold tuber $\mathrm{Zn}$ increase. The experiments showed no positive correlation between Fe fertilization and $\mathrm{Fe}$ concentration in tubers. Moreover, the study showed a strong effect of site on the concentration of $\mathrm{Fe}$ and $\mathrm{Zn}$ in tubers, and the tuber mineral concentrations across sites and treatments were negatively correlated with tuber yield.

Conclusions The results confirmed the proof of concept that Andean potato cultivars can be agronomically $\mathrm{Zn}$ biofortified with foliar and soil applied Zn fertilizers. Tuber Fe concentrations of Andean potatoes were not increased with $\mathrm{Fe}$ fertilization.

Keywords Potato $\cdot$ Biofortification $\cdot$ Fertilizer $\cdot$ Zinc . Iron · Andigenum Group

\section{Introduction}

Potato (Solanum tuberosum L.) production in the developing world surpassed potato production in the developed world for the first time in 2005 and is increasingly used as a staple food farmed and consumed by poor people (Devaux et al. 2014). In today's world more than a billion people eat potatoes regularly. Potato has been highly recommended by the Food and Agriculture Organization (FAO) as a food security crop as the world faces uncertainties in the food supply to an exponentially growing population with an increased demand for 
food (FAO 2009). This nutritious crop, and its high diversity of varieties, was first domesticated in the Andes of South America and it continues to be one of the most accessible foods in the rural areas of the Andes. A study done in the Central Andean Highlands in Huancavelica, Peru, identified that women in this area have a mean intake of $800 \mathrm{~g}$ of potato everyday (Anonymous 2003). In such areas where the potato is a dietary mainstay, the nutritional value of the tubers consumed contributes significantly to human nutrition and merits significant research investment for its improvement.

Micronutrient malnutrition, also known as hidden hunger, is the most widespread nutritional problem in the world today, especially for women, infants, and children (Frossard et al. 2000; Nestel et al. 2006; Stein 2010). It has been estimated that more than $60 \%$ of the world's population are iron (Fe) dietary deficient and more than $30 \%$ are zinc $(\mathrm{Zn})$ dietary deficient (White et al. 2009). Iron deficiency leads to anemia, reduces physical growth and cognitive development in young children, and is estimated to be responsible for a large proportion of the world's maternal deaths (Gibson 2012). Zinc affects multiple aspects of the human immune system and is critical to the function of more than 300 biological enzymes (McCall et al. 2000). Symptoms of $\mathrm{Zn}$ deficiency include stunting, diarrhea and pneumonia in children, and $\mathrm{Zn}$ deficiency contributes significantly to recurrent infections and infant mortality (Stein 2010). In contrast to Fe, $\mathrm{Zn}$ is not significantly stored in the human body and must be ingested daily (King 2011). Iron and zinc deficiencies are highly prevalent in developing countries, but are also common in industrialized countries (McClung et al. 2006; Gibson 2012). Many industrialized crops contain inherently low mineral concentrations as production is mainly geared to produce volume and appearance only. Modern human diets are, therefore, typically dominated by energydense but nutrient-poor foods that lack sufficient $\mathrm{Zn}$ for people's adequate nutrition (Graham et al. 2001; White and Broadley, 2011). Moreover, the prevalence of $\mathrm{Fe}$ and $\mathrm{Zn}$ deficiency is especially high in areas with low intake of animal products and high intake of phytates and phenolic compounds, which reduce $\mathrm{Fe}$ and $\mathrm{Zn}$ bioavailability, e.g. in Andean diets with high intake of low Fe and $\mathrm{Zn}$ containing grains and legumes (Bhan et al. 2001). According to Grandy et al. (2010), Ecuador and Bolivia have the highest national prevalences of anemia, caused by iron deficiency, in Latin
America. In recent years governmental programs (e.g., "The zero malnutrition program" in Bolivia) have aimed to reduce micronutrient malnutrition in the Andean countries, mainly through food supplementation programs. Nevertheless, extremely high rates of $\mathrm{Fe}$ and $\mathrm{Zn}$ deficiencies are still found in rural communities. In Peru, $21.9 \%$ national prevalence in rural areas of chronic malnutrition in children below 5 years of age was reported for 2014, but this prevalence is significantly higher in many isolated and poor communities (Dolores-Maldonado et al. 2015). In Ecuador, as in most developing countries, $\mathrm{Zn}$ and Fe deficiency is a public health concern, the Ministry of Public Health has reported the national prevalence of $\mathrm{Zn}$ deficiency in women in the childbearing age to be higher than $50 \%$, and the prevalence of $\mathrm{Zn}$ and Fe deficiency in children below 5 years of age to be 29 and $26 \%$, respectively (Freire et al. 2013).

Biofortification of crops is increasingly being used to combat micronutrient malnutrition. Biofortification is the process of making plant foods more nutritious as the plants are growing instead of having nutrients added to food when it is processed. Genetic biofortification aims at selecting crop varieties that are able to acquire nutrients and to accumulate them in their edible parts, or breeding crops (conventional breeding or genetic engineering) to increase their nutritional value. Agronomic biofortification, on the other hand, aims to enhance the concentrations of nutrients in the edible parts of crops through the use of agricultural techniques (e.g., usage of fertilizers containing micronutrients such as $\mathrm{Zn}$ ). To achieve both genetic and agronomic biofortification plant nutrients have to be present in the crop environment in plant available form. If mineral plant nutrients are absent they must be applied to crops as fertilizers. It is, thus, expected that successful biofortification is best achieved through a combination of genetic and agronomic biofortification processes (Cakmak 2008; White and Broadley 2011; Joy et al. 2015).

As potato is widely grown around the world where it is increasingly becoming the main staple food, the International Potato Center (CIP) and its partners are working to improve human nutrition through biofortification of potato. CIP has undertaken biofortification as a breeding objective, principally targeting $\mathrm{Fe}, \mathrm{Zn}$ and vitamin $\mathrm{C}$, but also evaluating concentrations of (anti-)nutrients such as phytates and phenolic compounds (Andre et al. 2007, 2015; Burgos et al. 2009; Paget et al. 2014). To support ongoing 
efforts in genetic biofortification, agronomic biofortification with micronutrients has been promoted as a cost-effective and fast approach to fight micronutrient malnutrition (Cakmak 2008, 2009; White and Broadley, 2009), and has been studied as a public health intervention with potential to reach a high number of households through fertilizer subsidy schemes (Joy et al. 2015). For example, $\mathrm{Zn}$ concentrations have been increased significantly with $\mathrm{Zn}$ fertilizer in wheat (Cakmak et al., 2010; Zhang et al. 2012; Zou et al. 2012; Velu et al. 2014; Joy et al. 2015), in rice (Jiang et al. 2008; Joy et al. 2015; Phattarakul et al. 2012), in maize (Joy et al. 2015; Puga et al. 2013), and in sorghum (Puga et al. 2013). In contrast to Zn biofortification, the scientific literature generally agrees that $\mathrm{Fe}$ concentration is difficult to increase in cereals and other crops with foliar and soil applications of inorganic Fe fertilizers (Gupta 1991; Aciksoz et al. 2011, Velu et al. 2014). The main reason being that soil applied Fe is largely converted into plant-unavailable $\mathrm{Fe}^{3+}$ forms and, therefore, rapidly becomes unavailable to plants (Rengel et al. 1999). Consequently, foliar application of synthetic Fe-chelates and $\mathrm{FeSO}_{4}$ is considered to be more effective Fe fertilizers (Rengel et al. 1999).

To date, only limited data are available on agronomic biofortification in potato, the world's third most important food crop following rice and wheat, and in other root and tuber crops (White and Broadley 2011). In one study, White et al. (2012) reported that potato tuber Zn concentrations could be increased about 2-fold in cultivar Maris Piper, a tetraploid European potato (Solanum tuberosum L. Chilotanum Group) type, using foliar $\mathrm{Zn}$ fertilizers, zinc sulphate and zinc oxide.

Considering the serious consequences of $\mathrm{Fe}$ and $\mathrm{Zn}$ malnutrition in rural Andean communities, and the key role of potato in Andean food systems, exploration of the potential for agronomic biofortification in the high diversity of Andean potato cultivars (Solanum tuberosum L. Andigenum Group) may be of great economical value. Therefore, CIP, Ecuador's National Agricultural Research Institute (INIAP) and the Polytechnic University of Chimborazo (ESPOCH) conducted a study to evaluate the potential role of a fertilization approach to increase $\mathrm{Fe}$ and $\mathrm{Zn}$ concentrations in Andean potato cultivars through a series of experiments in Ecuador. The aim of this study was to investigate the proof-of-concept that agronomic practices can improve the nutritional value of Andean potato. The present paper, thus, provides data on the biological potential of
$\mathrm{Fe}$ and $\mathrm{Zn}$ fertilization in biofortification of Andean potato tubers.

\section{Materials and methods}

Greenhouse pot experiments with Fe and Zn fertilizer

In 2012 four potato greenhouse experiments were conducted at the National Agricultural Research Institute of Ecuador's (INIAP) Santa Catalina Experiment station near the capital Quito with the cultivars INIAPNatividad and Chaucha roja. Two experiments were done with Fe fertilizer applied to soil and foliage, and two experiments with $\mathrm{Zn}$ fertilizer applied to soil and foliage. To facilitate the management of the study individual experiments with potted plants were done with each of the two cultivars INIAP-Natividad and Chaucha roja, Table 1 presenting the genetic origin of the cultivars. The same experimental design was used in the four greenhouse experiments with 8 replicates; a two-way factorial with the foliar applications in the main plots and soil application levels in the sub-plots. For operational reasons and to minimize the risk of drift of foliar applications among sub-plots the rows of experimental units receiving foliar applications were placed in vicinity. In the experiments with $\mathrm{Fe}$ fertilizer the plants were grown under the following soil Fe treatments; 0, 25, 50,

Table 1 Genetic origins of Andean potato cultivars (Solanum tuberosum Andigenum Group) evaluated in greenhouse pot experiments and field trials with Fe and $\mathrm{Zn}$ fertilizer in Ecuador

Potato cultivars

\begin{tabular}{ll}
\hline Name & Pedigree \\
\hline $\begin{array}{l}\text { INIAP-Natividad } \\
\text { (tetraploid) }\end{array}$ & $\begin{array}{l}\text { Solanum andigenum } \times \\
(\text { S. } \text { phureja } \times \text { S. pausissectum })\end{array}$ \\
$\begin{array}{l}\text { INIAP-Puca shungo } \\
\text { (triploid) }\end{array}$ & S. andigenum $\times$ S. phureja \\
$\begin{array}{l}\text { Chaucha amarilla } \\
\text { (diploid) }\end{array}$ & S. phureja \\
$\begin{array}{l}\text { Chaucha roja } \\
\text { (diploid) }\end{array}$ & Native Andean landrace \\
Coneja negra & S. phureja \\
(tetraploid) & Native Andean landrace \\
\hline
\end{tabular}

${ }^{\text {a }}$ Cultivars tested in greenhouse pot experiments

${ }^{\mathrm{b}}$ Cultivars tested in field trials with $\mathrm{Fe}$ and $\mathrm{Zn}$ fertilizer

${ }^{\mathrm{c}}$ Cultivar tested in field trials with foliar and soil-applied $\mathrm{Zn}$ fertilizers 
$75,100 \mathrm{mg} \mathrm{Fe} \mathrm{kg}^{-1}$ soil substrate, applied as an amino acid based Fe complex (Trazex Fe, Cosmocel SA, $220 \mathrm{~g}$ $\mathrm{Fe} \mathrm{kg}^{-1}$ ) (see Fig. 1). Foliar Fe treatments comprised of $0 \mathrm{mM}(0 \% \mathrm{w} / \mathrm{v})$ and $6.71 \mathrm{mM}(0.0375 \% \mathrm{w} / \mathrm{v})$ aqueous solution of $\mathrm{Fe}$, applied as EDTA-chelated Fe (Kelik Fe, Atlántica, $7.5 \% \mathrm{w} / \mathrm{v}$ ). In the $\mathrm{Zn}$ experiments the following soil treatments were used: 0, 8, 16, 24 and $32 \mathrm{mg} \mathrm{Zn}$ $\mathrm{kg}^{-1}$ soil substrate, applied as an amino acid based $\mathrm{Zn}$ nutrient (Trazex Zn, Cosmocel SA, $250 \mathrm{~g} \mathrm{Zn} \mathrm{kg}^{-1}$ ), and foliar $\mathrm{Zn}$ treatments comprised of $0 \mathrm{mM}(0 \% \mathrm{w} / \mathrm{v})$ and $3.06 \mathrm{mM}(0.02 \% \mathrm{w} / \mathrm{v})$ aqueous solution of $\mathrm{Zn}$, applied as EDTA-chelated Zn (Kelik Zn, Atlántica, $10 \% \mathrm{w} / \mathrm{v}$ ). In all experiments, soil treatments were applied to the substrate in pots before planting. The soil substrate used (three-fifths sifted natural Andean soil, one-fifth volcanic pumice, and one-fifth commercial peat) was confirmed to have the following concentrations of extractable Fe prior to the experiments: $34 \mathrm{mg} \mathrm{kg}^{-1}$, modified Olsen extract, and extractable $\mathrm{Zn}: 3.8 \mathrm{mg} \mathrm{kg}^{-1}$, modified Olsen extract, and a pH of 6.29. The experimental unit consisted of one potato plant developed from one presprouted seed tuber in $5 \mathrm{~kg}$ of substrate in a 101 pot. Pots were amended with, $0.9,2.25,0.45,0.075,0.037,0.037$, $0.0075 \mathrm{~g}$ of $\mathrm{N}, \mathrm{P}_{2} \mathrm{O}_{5}, \mathrm{~K}_{2} \mathrm{O}, \mathrm{S}, \mathrm{Mg}, \mathrm{Mn}$ and $\mathrm{B}$, respectively, before planting. All four experiments were planted on July 4, 2012. Foliar applications of Fe and Zn were applied during early morning hours with manually operated knap-sack sprayers five times in each experiment; at $\mathrm{BBCH}$ (decimal code system) growth stages $60,65,70,75,80$. The average daily minimum temperature in the greenhouse was $5.8^{\circ} \mathrm{C}$, average daily

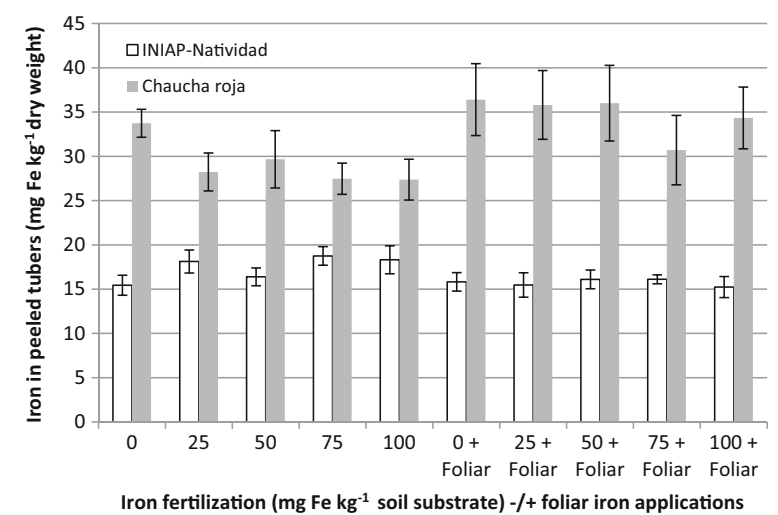

Fig. 1 Mean concentration of $\mathrm{Fe}$ in peeled tubers of potato cultivars INIAP-Natividad $(n=8)$ and Chaucha roja $(n=3)$ in greenhouse pot experiments as response to soil $\mathrm{Fe}$ applications without and with foliar Fe applications. Bars represent the standard error of the mean maximum temperature $29.5{ }^{\circ} \mathrm{C}$, and average relative humidity $57.1 \%$. Pots were irrigated manually with equal amounts of deionized water to each pot according to evapotranspiration measured with a lysimeter. A foliage supporting system was installed with plastic ribbons fastened to the potato plants to prevent stems from falling. The pesticides acephate and bupirimate were applied to all plants, equally, to control, insects and fungal diseases, respectively.

The haulms, i.e. above ground plant material (stems and leaves), were excised from the plants one day prior to harvest of tubers and roots. Harvest of tubers and roots in the four experiments was done on October 22, 2012. The fresh weights (FW) of haulms, tubers and roots, separately, were determined for each plant. Iron and zinc translocation to tubers was determined through the evaluation of plant biomass, tuber yield, and $\mathrm{Fe}$ and $\mathrm{Zn}$ concentration in peeled tubers, tuber peel, haulms and roots.

Field trials with $\mathrm{Fe}$ and $\mathrm{Zn}$ fertilizer

From 2012 to 2014 a field experiment with Fe and Zn fertilizer was replicated at three sites in Ecuador, twice at INIAP's Santa Catalina Experiment station (Trial 1 and Trial 2) and once at the Polytechnic University of Chimborazo's (ESPOCH) Tunshi Experiment station in the province of Chimborazo (Trial 3). The experiment involved the five cultivars; INIAP-Natividad, INIAPPuca shungo, Chaucha amarilla, Chaucha roja, Coneja negra (Table 1). Prior to the experiments, $30 \mathrm{sub}$ samples of soil were taken to a depth of $25 \mathrm{~cm}$ across each site to determine the chemical composition and the physical characteristics of the soils. Soil analyses were carried out at the Laboratory for Management of Soils and Water at INIAP's Santa Catalina Experiment station using standard methods of analysis (see Table 2).

The experiment was set up in a two-way factorial design with split-plots randomized in four complete blocks. The two factors were potato cultivar in the main plot and fertilizer treatment in the sub-plot. The experiment included the following six fertilizer treatments involving the same sources of $\mathrm{Fe}$ and $\mathrm{Zn}$ fertilizer that were applied in the greenhouse experiments: F0 = control, F1 $=40 \mathrm{~kg} \mathrm{Fe} \mathrm{ha}^{-1}$ applied as an amino acid based Fe complex (Trazex Fe, Cosmocel SA, $220 \mathrm{~g} \mathrm{Fe} \mathrm{kg}^{-1}$ ) + $20 \mathrm{~kg} \mathrm{Zn} \mathrm{ha}^{-1}$ applied as an amino acid based zinc nutrient (Trazex Zn, Cosmocel SA, $250 \mathrm{~g} \mathrm{Zn} \mathrm{kg}^{-1}$ ) incorporated to soil at planting; F2 $=40 \mathrm{~kg} \mathrm{Fe} \mathrm{ha}^{-1}$ 
Table 2 Site, soil characteristics and agricultural practices of 3 field trials with Fe and Zn fertilizer in Ecuador from 2012 to 2014

\begin{tabular}{|c|c|c|c|}
\hline Experiment & Trial 1 & Trial 2 & Trial 3 \\
\hline \multicolumn{4}{|l|}{ Site characteristics } \\
\hline Location, Province & Santa Catalina, Pichincha & Santa Catalina, Pichincha & Tunshi, Chimborazo \\
\hline Latitude and longitude & $0^{\circ} 22^{\prime} 12.6^{\prime \prime} \mathrm{S} 78^{\circ} 33^{\prime} 20.4^{\prime \prime} \mathrm{W}$ & $0^{\circ} 22^{\prime} 15.1^{\prime \prime} \mathrm{S} 78^{\circ} 33^{\prime} 25.8^{\prime \prime} \mathrm{W}$ & $1^{\circ} 44^{\prime} 49.7^{\prime \prime S} 78^{\circ} 37^{\prime} 39.3^{\prime \prime} \mathrm{W}$ \\
\hline Altitude (m.a.s.l.) & 3058 & 3058 & 2731 \\
\hline Avg. temp. $\left({ }^{\circ} \mathrm{C}\right)$ & 11.5 & 11.7 & 14.2 \\
\hline $\begin{array}{l}\text { Precipitation (mm accumulated from } \\
\text { planting to harvest) }\end{array}$ & 282 & 403 & 223 \\
\hline \multicolumn{4}{|l|}{ Soil chemical composition before planting } \\
\hline $\begin{array}{l}\text { Nitrogen }\left(\mathrm{mg} \mathrm{N}-\mathrm{NH}_{4}^{+} \mathrm{kg}^{-1}\right) \\
\text { (Modified Olsen extract) }\end{array}$ & $84 \mathrm{H}^{\mathrm{a}}$ & $51 \mathrm{M}$ & $29.0 \mathrm{~L}$ \\
\hline $\begin{array}{l}\text { Phosphorous }\left(\mathrm{mg} \mathrm{kg}^{-1}\right) \\
\text { (Modified Olsen extract) }\end{array}$ & $60 \mathrm{H}$ & $37 \mathrm{H}$ & $37.0 \mathrm{H}$ \\
\hline $\begin{array}{l}\text { Potassium meq/100 ml } \\
\text { (Modified Olsen extract) }\end{array}$ & $0.42 \mathrm{H}$ & $0.19 \mathrm{~L}$ & $0.84 \mathrm{H}$ \\
\hline Ca meq/100 ml (Modified Olsen extract) & $6.50 \mathrm{M}$ & $6.82 \mathrm{M}$ & $9.20 \mathrm{H}$ \\
\hline Mg meq/100 ml (Modified Olsen extract) & $0.58 \mathrm{~L}$ & $0.49 \mathrm{~L}$ & $5.50 \mathrm{H}$ \\
\hline Iron $\left(\mathrm{mg} \mathrm{kg}^{-1}\right)$ (Modified Olsen extract) & $290 \mathrm{H}$ & $175 \mathrm{H}$ & $56 \mathrm{H}$ \\
\hline Zinc (mg kg ${ }^{-1}$ ) (Modified Olsen extract) & $3.3 \mathrm{M}$ & $3.7 \mathrm{M}$ & $1.60 \mathrm{~L}$ \\
\hline \multicolumn{4}{|l|}{ Soil physical characteristics before planting } \\
\hline Organic matter $(\%)$ (Potassium dichromate) & $8.90 \mathrm{H}$ & $9.50 \mathrm{H}$ & $2.00 \mathrm{M}$ \\
\hline $\mathrm{pH}(1: 2.5$ soil-water $)$ & 5.59 & 5.61 & 7.28 \\
\hline Soil texture & $\begin{array}{l}\text { Sandy loam (black } \\
\text { Andean andisol) }\end{array}$ & $\begin{array}{r}\text { Sandy loam (black } \\
\text { Andean andisol) }\end{array}$ & $\begin{array}{l}\text { Sandy loam (Andean } \\
\text { andisol) }\end{array}$ \\
\hline \multicolumn{4}{|l|}{ Agricultural practices } \\
\hline Previous crop & Triticum aestivum & Fallow & Hordeum vulgare \\
\hline Planting date & 27 March 2012 & 12 April 2013 & 15 November 2013 \\
\hline Harvest dates & 14 to 27 August 2012 & 18 to 30 September 2013 & 11 April to 26 June 2014 \\
\hline
\end{tabular}

${ }^{\mathrm{a}} \mathrm{H}=$ value considered to be high for plant nutrition, $\mathrm{M}=$ value considered to be medium for plant nutrition, $\mathrm{L}=$ value considered to be low for plant nutrition, according to recommendations of INIAP's Laboratory for Management of Soils and Water at the Santa Catalina Experiment station

applied to soil at planting as an amino acid based $\mathrm{Fe}$ complex (Trazex Fe, Cosmocel SA, $220 \mathrm{~g} \mathrm{Fe} \mathrm{kg}^{-1}$ ); $\mathrm{F} 3=20 \mathrm{~kg} \mathrm{Zn} \mathrm{ha}^{-1}$ applied to soil at planting as an amino acid based zinc nutrient (Trazex $\mathrm{Zn}$, Cosmocel $\left.\mathrm{SA}, 250 \mathrm{~g} \mathrm{Zn} \mathrm{kg}^{-1}\right)$; F4 = $3.06 \mathrm{mM}(0.02 \% \mathrm{w} / \mathrm{v})$ aqueous solution of $\mathrm{Zn}$ applied as EDTA-chelated Zn (Kelik Zn, Atlántica, $10 \%$ w/v) sprayed on foliage until run-off five times; once a week following the first spray 60 days after planting, $\mathrm{F} 5=6.71 \mathrm{mM}(0.0375 \% \mathrm{w} / \mathrm{v})$ aqueous solution of Fe, applied as EDTA-chelated Fe (Kelik Fe, Atlántica, $7.5 \% \mathrm{w} / \mathrm{v}$ ) sprayed on foliage until run-off 5 times; once a week following the first spray 55 days after planting.

The sub-plots with the cultivar-fertilizer treatment combinations consisted of four $3 \mathrm{~m}$-rows of potato plants. The distance between rows was $1.1 \mathrm{~m}$, and
$0.3 \mathrm{~m}$ between plants in a row; with a total of 40 plants per sub-plot. A strip of uncultivated land, $1.1 \mathrm{~m}$ wide, was left between sub-plots and between main plots. Soil preparation before planting was done following local practice, including tractor driven disk ploughing and harrowing.

All plots were fertilized equally with basic fertilizer in each trial according to soil analysis carried out immediately before planting (INIAP's Laboratory for Management of Soils and Water at the Santa Catalina Experiment station). Basic fertilization rates used in the trials can be found in the online Supplementary material file.

Planting of pre-sprouted tubers, fertilization, weeding, hilling, application of pesticides and harvest were done manually according to local farmer practice. 
Timing of hilling and harvest was done individually by cultivar according to the cultivars' phenological development. The experiments were primarily rainfed. During periods of low rainfall, all plots at the same site were irrigated with the same volume of water distributed by gravity. Pest and diseases were controlled with pesticides that do not contain significant concentrations of $\mathrm{Zn}$ or Fe: mandipropamid, chlorothalonil, azoxystrobin, propineb, lambda-cyhalothrin + thiamethoxam and acephate. Site descriptions and details on agricultural practices are shown in Table 2.

For micronutrient analysis of haulms and roots, two plants were collected randomly from each plot at onset of senescence. Following natural senescence, tuber yield was determined of the 9 centermost plants of the center row of each plot. For micronutrient analyses of potato tubers, $2 \mathrm{~kg}$ tuber sub-samples representing all tuber sizes per plot were taken at random from these same plants of each plot.

Immediately after tuber harvest in Trial 1 , the soil of each sub-plot was homogenized with the use of a hoe, and a soil sample was taken from the area of the two center rows of each sub-plot made up of 25 subsamples of 0 to $25 \mathrm{~cm}$ depth in each of block 2, 3 and 4 and used for determining the residual $\mathrm{Fe}$ and $\mathrm{Zn}$ concentrations in the sub-plot soil after harvest $\left(\mathrm{mg} \mathrm{kg}^{-1}\right.$, modified Olsen extract).

Agronomic Zn-biofortification of potato with foliar and soil applied $\mathrm{Zn}$ fertilizers

In 2013 to 2014 agronomic biofortification of potato tubers with $\mathrm{Zn}$ was assessed in potato cultivar INIAPNatividad at two locations in farmers' fields in the province of Chimborazo in Ecuador. Prior to the experiments, 25 sub-samples of soil were taken to a depth of $25 \mathrm{~cm}$ across each site to determine soil chemical composition and physical characteristics (see Table 3). Two experiments were conducted at each site. One experiment was designed to evaluate foliar applications of $\mathrm{Zn}$, and the other one soil applied $\mathrm{Zn}$, on concentration of $\mathrm{Zn}$ in harvested tubers. The two experiments replicated at the two sites used the same one-way factorial design with five $\mathrm{Zn}$ fertilizer treatments randomized in four complete blocks. Geographical coordinates, site descriptions and details on agricultural practices are detailed in Table 3. The experiment with foliar applications included the following five $\mathrm{Zn}$ treatments: $0,1.25,2.5,5$ and $10 \mathrm{~kg} \mathrm{Zn} \mathrm{ha}{ }^{-1}$ as $0,0.02,0.04,0.08,0.16 \%$ (w/v) aqueous solution of $\mathrm{Zn}$, respectively, in $1250 \mathrm{~L} \mathrm{ha}^{-1}$ applied 5 times in weekly foliar sprays with the first spray 55 days after planting. The experiment with soil applications included the following five $\mathrm{Zn}$ treatments: $0,10,20,30$ and $40 \mathrm{~kg} \mathrm{ha}^{-1}$, incorporated to the soil in furrow at planting. The same $\mathrm{Zn}$ fertilizers used in the experiments previously described were used; soil $\mathrm{Zn}$ was applied as amino acid based zinc (Trazex $\mathrm{Zn}$, Cosmocel SA, $250 \mathrm{~g} \mathrm{Zn} \mathrm{kg}^{-1}$ ), and foliar $\mathrm{Zn}$ as EDTA-chelated Zn (Kelik Zn, Atlántica, $10 \%$ p/v).

In both experiments the plots consisted of four $4.8 \mathrm{~m}$ rows of potato plants. The distance between rows was $1.1 \mathrm{~m}$, and $0.3 \mathrm{~m}$ between plants in a row, a total of 64 plants per plot. A $1.1 \mathrm{~m}$ strip of uncultivated land was left between plots. Soil preparation before planting was done following local practice, including ploughing, harrowing and hilling. All plots were fertilized equally with basic fertilizer in each experiment according to soil analysis carried out immediately before planting (INIAP's Laboratory for Management of Soils and Water at the Santa Catalina Experiment station). The fertilization rate was $120 \mathrm{~kg} \mathrm{~N} \mathrm{ha}^{-1}$ for site 1 and $160 \mathrm{Kg}$ $\mathrm{N} \mathrm{ha}^{-1}$ for site 2, and $200 \mathrm{~kg} \mathrm{P}_{2} \mathrm{O}_{5} \mathrm{ha}^{-1}, 120 \mathrm{~kg} \mathrm{~K} 2 \mathrm{O}$ $\mathrm{ha}^{-1}, 60 \mathrm{~kg} \mathrm{Ca}, 25 \mathrm{~kg} \mathrm{Mg} \mathrm{ha}^{-1}$ and $30 \mathrm{~kg} \mathrm{~S} \mathrm{ha}^{-1}$ for both sites. The sources were the same as the ones used in Trial 2 described in the online Supplementary material file, but with the use of calcium nitrate $15.5 \% \mathrm{~N}$ $26.3 \% \mathrm{CaO}$ instead of ammonium nitrate. All $\mathrm{P}, \mathrm{K}$, $\mathrm{Ca}, \mathrm{Mg}$ and $\mathrm{S}$ and $50 \%$ of the $\mathrm{N}$ were incorporated to the soil in furrows at planting, $25 \% \mathrm{~N}$ (urea) was applied at first hilling, and $25 \% \mathrm{~N}$ (urea) was applied at second hilling.

Planting of pre-sprouted tubers, fertilization, weeding, hilling, application of pesticides and harvest was done manually following local farmer practice. The experiments were rainfed. Pest and diseases were controlled with the same pesticides described above. Site characteristics and details on agricultural practices are shown in Table 3.

At 50 days after planting percentage of emerged plants was evaluated for each plot. At BBCH 65, with $50 \%$ of flowers in the first inflorescence open, plant height was evaluated of each plot; the mean of ten randomly selected plants measured from ground level to the main stem apex.

For micronutrient analysis of haulms and roots, two plants were collected randomly from each plot at onset of senescence. At harvest, tuber yield was determined of the 14 centermost plants in each of the two center rows 
Table 3 Site, soil characteristics and agricultural practices of field experiments with soil and foliar applied Zn fertilizers in farmers' fields in Ecuador from 2013 to 2014

\begin{tabular}{|c|c|c|}
\hline Site & Site 1 & Site 2 \\
\hline \multicolumn{3}{|l|}{ Site characteristics } \\
\hline Location name, Province & Cortijo Bajo, Chimborazo & Pusniag, Chimborazo \\
\hline Latitude and longitude & $1^{\circ} 42^{\prime} 18.6^{\prime \prime} \mathrm{S} 78^{\circ} 34^{\prime} 20.5^{\prime \prime} \mathrm{W}$ & $1^{\circ} 32^{\prime} 26.6^{\prime \prime} \mathrm{S} 78^{\circ} 33^{\prime} 55.4^{\prime \prime} \mathrm{W}$ \\
\hline Altitude (m.a.s.1.) & 3149 & 3502 \\
\hline Avg. temp. $\left({ }^{\circ} \mathrm{C}\right)$ & 13.9 & 12.7 \\
\hline Precipitation (mm accumulated during cropping season) & 344 & 533 \\
\hline \multicolumn{3}{|l|}{ Soil chemical composition before planting } \\
\hline Nitrogen $\left(\mathrm{mg} \mathrm{N}-\mathrm{NH}_{4}{ }^{+} \mathrm{kg}^{-1}\right)$ (Modified Olsen extract) & $57.0 \mathrm{M}$ & $30.0 \mathrm{M}$ \\
\hline Phosphorous (mg kg${ }^{-1}$ ) (Modified Olsen extract) & $19.0 \mathrm{M}$ & $102.0 \mathrm{H}$ \\
\hline Calcium meq/100 ml (Modified Olsen extract) & $16.20 \mathrm{H}$ & $3.40 \mathrm{~L}$ \\
\hline Magnesium meq/100 ml (Modified Olsen extract) & $3.60 \mathrm{M}$ & $1.70 \mathrm{~L}$ \\
\hline Potassium meq/100 ml (Modified Olsen extract) & $0.35 \mathrm{M}$ & $0.11 \mathrm{~L}$ \\
\hline Iron $\left(\mathrm{mg} \mathrm{kg}^{-1}\right)$ (Modified Olsen extract) & $361.0 \mathrm{H}$ & $140.0 \mathrm{H}$ \\
\hline Zinc (mg kg ${ }^{-1}$ ) (Modified Olsen extract) & $2.40 \mathrm{~L}$ & $1.30 \mathrm{~L}$ \\
\hline \multicolumn{3}{|l|}{ Soil physical characteristics before planting } \\
\hline Organic matter $(\%)$ (Potassium dichromate) & $7.70 \mathrm{H}$ & $1.40 \mathrm{~L}$ \\
\hline $\mathrm{pH}(1: 2.5$ soil-water $)$ & 6.27 & 6.08 \\
\hline Soil texture & Sandy loam (black Andean andisol) & Sandy loam (Andean andisol) \\
\hline \multicolumn{3}{|l|}{ Agricultural practices } \\
\hline Previous crop & Triticum aestivum & Fallow \\
\hline Planting date & 9 October 2013 & 8 October 2013 \\
\hline Harvest date & 22 April 2014 & 2 April, 2014 \\
\hline
\end{tabular}

${ }^{\mathrm{a}} \mathrm{H}=$ value considered to be high for plant nutrition, $\mathrm{M}=$ value considered to be medium for plant nutrition, $\mathrm{L}=$ value considered to be low for plant nutrition, according to recommendations of INIAP's Laboratory for Management of Soils and Water at the Santa Catalina Experiment station

of each plot. For micronutrient analyses of potato tubers, $2 \mathrm{~kg}$ tuber sub-samples from each plot were taken at random from these same plants, considering all tuber sizes.

Immediately after tuber harvest, the soil of each subplot was homogenized with the use of a hoe, and a soil sample was taken from the area of the two center rows of each experimental unit made up of 25 subsamples taken to a depth of $25 \mathrm{~cm}$ and used for determining the residual $\mathrm{Zn}$ concentrations in the top soil of each experimental unit after harvest ( $\mathrm{mg} \mathrm{kg}^{-1}$, modified Olsen extract).

Determination of dry matter and mineral concentrations

In all experiments, tuber (peel and peeled tubers separately), haulm and root samples (total per plant) were washed in distilled water, prepared, oven-dried at $60^{\circ} \mathrm{C}$, dry weight (dw) determined, and analytical samples taken of $0.25 \mathrm{~g}$, and digested at $200{ }^{\circ} \mathrm{C}$ in $5 \mathrm{ml}$ of a solution $(5: 1) \mathrm{HNO}_{3}\left(65 \%\right.$, W/W) to $\mathrm{HClO}_{4}(70 \%$, $\mathrm{W} / \mathrm{W})$ ratio, following an adaptation of the methods described by Zasoski and Burau (1977) and Malavolta et al. (1989); the current standard method used by INIAP's Laboratory for Management of Soils and Water at the Santa Catalina Experiment station. Samples were analyzed for $\mathrm{Zn}$ and $\mathrm{Fe}$, by inductively coupled plasma optical emission spectrometry (ICPOES) (Optima 5300 DV, Perkin Elmer, USA).

\section{Statistical analysis}

All data were tested for outliers with the aid of boxplot charts prior to analysis of variance (ANOVA) combined over sites and by site/year separately. When significant differences were found in ANOVA, means were compared using Tukey's test at $P \leq 0.05$. Multiple treatment 
comparisons were made using orthogonal contrasts. Associations between variables were determined using Pearson correlation coefficients. All statistical analyses were made with SAS 9.1 statistical software in the GLM procedure (SAS Institute Inc., Cary, NC). Atypical data were treated as missing values in the statistical analysis.

\section{Results}

Greenhouse pot experiments with Fe and Zn fertilizer

In the two experiments with the potato cultivar INIAPNatividad the plants developed as expected and data could be taken from all pots. In both experiments with the cultivar Chaucha roja some plants were affected with Verticillium disease and were eliminated from the experiments. At least three unaffected pots of each treatment in each experiment were maintained for collection and statistical analysis of data.

The greenhouse pot experiments showed no positive correlation between Fe fertilization and Fe concentration in tubers (Fig. 1). The two-factor ANOVA of the effects of $\mathrm{Fe}$ fertilization on concentration of $\mathrm{Fe}$ in peeled tubers revealed significant effects of foliar $\mathrm{Fe}$ applications (ANOVA table not shown; $P=0.0065$ in INIAP-Natividad and $P=0.0195$ in Chaucha roja). However, the Fe concentration in peeled tubers of cultivar INIAP-Natividad was significantly reduced when adding foliar Fe applications to the soil $\mathrm{Fe}$ rates used in the experiment (Tukey's test, $P<0.05$ ) (Fig. 1). The Fe concentration in peeled tubers ranged from 27.4 to 36.4 and 15.2 to $18.8 \mathrm{mg} \mathrm{Fe} \mathrm{kg}^{-1} \mathrm{dw}$ in cultivars Chaucha roja and INIAP-Natividad, respectively. The two-factor ANOVAs of the effects of foliar and soil applied $\mathrm{Fe}$ revealed a significant negative effect of foliar applied $\mathrm{Fe}$ on tuber yield in cultivar INIAP-Natividad; the mean tuber yields of soil Fe treatments without and with foliar applied Fe were 525 and $500 \mathrm{~g} \mathrm{plant}^{-1}$, respectively. The treatments that resulted in higher tuber Fe concentrations in Chaucha roja were also the treatments with the lowest yields (Tuber yield data not shown). Indeed, plants that received foliar Fe showed Fe toxicity symptoms on leaves in both cultivars. Iron concentrations in foliage of INIAP-Natividad plants receiving both soil and foliar applied $\mathrm{Fe}$ reached $1079 \mathrm{mg} \mathrm{Fe} \mathrm{kg}^{-1} \mathrm{dw}$, and plants receiving only soil applied Fe reached $467 \mathrm{mg} \mathrm{Fe}$ $\mathrm{kg}^{-1} \mathrm{dw}$.
The two-factor ANOVA of the effects of $\mathrm{Zn}$ fertilization on peeled tuber $\mathrm{Zn}$ concentration showed a highly significant effect of foliar applied $\mathrm{Zn}$ in both cultivars $(P<0.0001)$, and also a significant effect of soil applied Zn $(P=0.0598$ in INIAP-Natividad and $P=0.0007$ in Chaucha roja), but no interaction effects (ANOVA table not shown). Up to a 2.69-fold mean increase in $\mathrm{Zn}$ concentration in peeled potato tubers of cultivar INIAP-Natividad was seen with combined foliar and soil applied Zn (Fig. 2). Application of the highest level of soil $\mathrm{Zn}$ plus foliar $\mathrm{Zn}$ increased the mean $\mathrm{Zn}$ concentration in peeled tubers from 8.1 in the control to 21.6, and from 12.5 to $30.9 \mathrm{mg} \mathrm{Zn} \mathrm{kg}{ }^{-1} \mathrm{dw}$ in INIAPNatividad and Chaucha roja respectively (Fig. 2). Zinc concentrations in foliage of INIAP-Natividad plants receiving both soil and foliar applied $\mathrm{Zn}$ reached $282 \mathrm{mg} \mathrm{Zn} \mathrm{kg}^{-1} \mathrm{dw}$, and plants receiving only soil applied $\mathrm{Zn}$ reached $107 \mathrm{mg} \mathrm{Zn} \mathrm{kg}^{-1} \mathrm{dw}$ with the highest soil $\mathrm{Zn}$ application (32 $\mathrm{mg} \mathrm{Zn} \mathrm{kg}^{-1}$ soil substrate). The ANOVA showed non-significant effects of foliar and soil applied $\mathrm{Zn}$ on tuber yield in both cultivars (ANOVA tables not shown). Tuber yields in the two pot experiments with the same cultivar were in a similar range; 469 to $537 \mathrm{~g} \mathrm{plant}^{-1}$ and 242 to $379 \mathrm{~g} \mathrm{plant}^{-1}$ in INIAP-Natividad and Chaucha roja, respectively.

Field trials with Fe and $\mathrm{Zn}$ fertilizer

The three trials developed successfully with only few outlying data points being excluded. Missing data were mainly caused by rain flooding or uneven seed quality

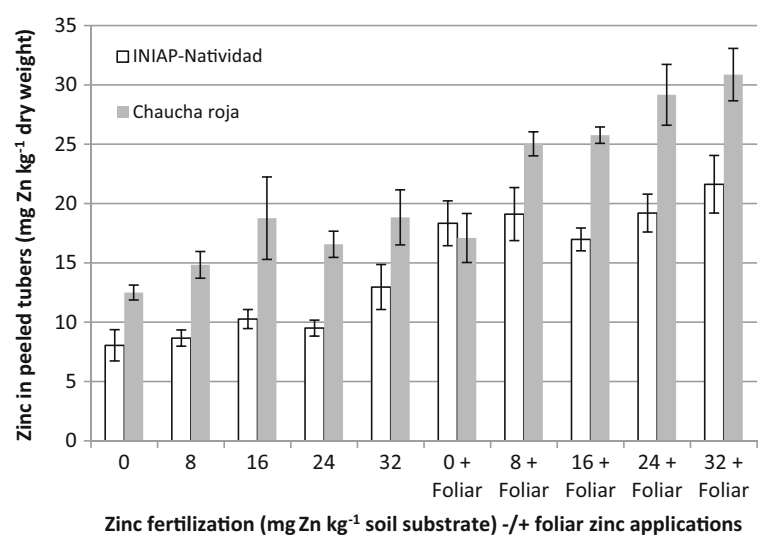

Fig. 2 Mean concentration of $\mathrm{Zn}$ in peeled tubers of potato cultivars INIAP-Natividad $(n=8)$ and Chaucha roja $(n=3)$ in greenhouse pot experiments as response to soil $\mathrm{Zn}$ applications without and with foliar $\mathrm{Zn}$ applications. Bars represent the standard error of the mean 
resulting in bad plant emergence. No toxicity symptoms were apparent in the $\mathrm{Zn}$ treatments, but toxicity symptoms were seen in the diploid cultivars that received foliar Fe fertilizer in all trials. The total mean tuber yield among trials varied between 10.4 and $35.6 \mathrm{t} \mathrm{ha}^{-1}$ (Table 4), which illustrates a strong effect of site and planting time on each trial. In Ecuador potato can be planted year round. Trial 1 was planted during the end of the main planting season at the Santa Catalina Experiment station near Quito, whereas Trial 2 was planted later than the normal planting season. Both Trials 1 and 2 received complementary, but suboptimal irrigation. This was especially the case for Trial 2 . Trial 3 at the Tunshi Experiment station in the province of Chimborazo was intensively managed with irrigation.

The three trials showed a non-significant effect of the $\mathrm{Fe}$ and $\mathrm{Zn}$ fertilizer treatments on potato tuber yield (Table 5). As expected the trials resulted in significant different tuber yields among cultivars with, generally, higher yields in the breed cultivars compared to the native landrace cultivars and with the lowest yields in the diploid cultivars (Tables 4 and 5).

The three trials showed a highly significant effect of cultivar on tuber Fe concentration (Tables 6 and 7). A significant effect of fertilizer treatments on tuber $\mathrm{Fe}$ concentration was also detected (Table 7). However, the Tukey ranking did not reveal significant differences in tuber Fe concentration between treatments that had received $\mathrm{Fe}$ fertilizer and the unfertilized control plots (Table 6).

A highly significant effect of $\mathrm{Fe}$ and $\mathrm{Zn}$ fertilizer treatments on tuber $\mathrm{Zn}$ concentration in peel (data not shown) and peeled potato tubers was detected in all three field trials (Table 8). The $\mathrm{Zn}$ concentration in peeled tubers increased significantly in 4 out of 6

Table 4 Mean tuber yields ( $\mathrm{tha}^{-1}$ ) of 5 Andean potato cultivars in 3 field trials in Ecuador with Fe and $\mathrm{Zn}$ fertilizer from 2012 to 2014

\begin{tabular}{llll}
\hline Cultivar & Trial 1 & Trial 2 & Trial 3 \\
\hline Chaucha roja & $25.3 \mathrm{c}$ & $5.8 \mathrm{~d}$ & $21.2 \mathrm{~b}$ \\
Chaucha amarilla & $28.0 \mathrm{c}$ & $8.4 \mathrm{c}$ & $22.2 \mathrm{~b}$ \\
Coneja negra & $36.8 \mathrm{~b}$ & $12.6 \mathrm{~b}$ & $23.0 \mathrm{~b}$ \\
INIAP-Natividad & $45.4 \mathrm{a}$ & $15.2 \mathrm{a}$ & $30.5 \mathrm{a}$ \\
INIAP-Puca Shungo & $42.4 \mathrm{a}$ & $10.0 \mathrm{c}$ & $31.8 \mathrm{a}$ \\
Mean & 35.6 & 10.4 & 25.7 \\
\hline
\end{tabular}

Values in the same column followed by the same letter are not significantly different according to Tukey's test $(P<0.05)$ treatment-by-site combinations with soil $\mathrm{Zn}$ fertilizer, and in 2 out of 3 treatment-by-site combinations with foliar $\mathrm{Zn}$ fertilizer (Table 6). As expected a significant effect was also found of cultivar on tuber $\mathrm{Zn}$ concentration with the diploid Chaucha cultivars showing the highest $\mathrm{Zn}$ concentrations (Tables 6 and 8). An interaction effect between fertilizer treatment and potato cultivar on mineral tuber concentrations was only found in Trial 3; $P=0.0148$ for $\mathrm{Fe}$, and $P=0.0582$ for $\mathrm{Zn}$. The potato genotypes that showed high tuber $\mathrm{Zn}$ concentrations in the absence of $\mathrm{Zn}$ fertilization also showed even higher tuber $\mathrm{Zn}$ concentrations following $\mathrm{Zn}$ fertilization (data not shown). The mean $\mathrm{Fe}$ and $\mathrm{Zn}$ concentration across cultivars varied significantly among trials (Table 6), which illustrates a strong effect of site and planting time on tuber mineral concentrations. A comparison of the mean mineral concentrations with the mean tuber yields in the three field trials with $\mathrm{Fe}$ and $\mathrm{Zn}$ fertilizer reveal that the micronutrient concentrations in tubers have a negative correlation with tuber yield. Pearson correlation coefficients between peeled tuber $\mathrm{Zn}$ concentration ( $\mathrm{mg} \mathrm{kg}^{-1}$ dry weight) and tuber yield $\left(\mathrm{t} \mathrm{ha}^{-1}\right)$ of all cultivar-treatment combinations were $-0.580(P<0.0001),-0.502(P<0.0001),-0.551$ $(P<0.0001)$ in Trial 1, 2 and 3, respectively. Pearson correlation coefficients between peeled tuber Fe concentration ( $\mathrm{mg} \mathrm{kg}^{-1}$ dry weight) and tuber yield $\left(\mathrm{t} \mathrm{ha}^{-1}\right)$ of all cultivar-treatment combinations for Trial 1, 2 and 3, respectively, were $-0.494(P<0.0001),-0.247$ ( $P=$ $0.027),-0.617(P<0.0001)$. Interestingly, tuber $\mathrm{Zn}$ concentration (Table 6 ) and $\mathrm{Zn}$ extraction by potato tubers (Table 9) were lowest in Trial 3. The mean extraction of $\mathrm{Fe}$ and $\mathrm{Zn}$ in peeled tubers varied significantly among cultivars and among trials (Table 9).

The residual Fe concentrations (mean \pm standard error, $\mathrm{mg} \mathrm{kg}^{-1}$ ) in the soil at harvest in Trial 1 were: control $=193 \pm 7.05, \mathrm{~F} 1=197 \pm 5.91 ; \mathrm{F} 2=195 \pm 4.88$; $\mathrm{F} 3=195 \pm 6.43 ; \mathrm{F} 4=201 \pm 7.09 ; \mathrm{F} 5=193 \pm 5.97$. The residual $\mathrm{Zn}$ concentrations (mean \pm standard error, $\mathrm{mg}$ $\mathrm{kg}^{-1}$ ) in the soil at harvest in Trial 1 were: control $=2.2$ $\pm 0.08, \mathrm{~F} 1=7.3 \pm 0.56 ; \mathrm{F} 2=2.2 \pm 0.10 ; \mathrm{F} 3=6.5 \pm 0.58$; $\mathrm{F} 4=2.2 \pm 0.08 ; \mathrm{F} 5=2.1 \pm 0.07$.

Agronomic Zn-biofortification of potato with foliar and soil applied $\mathrm{Zn}$ fertilizers

The individual ANOVAs of the effect of $\mathrm{Zn}$ fertilizer rates on tuber yield only revealed a significant effect of foliar $\mathrm{Zn}$ rates at the Pusniag site $(P=0.0104)$ 
Table 5 Individual analysis of variance (ANOVA) for main plot effect cultivar and subplot effect fertilizer treatment (zinc and/or iron) on tuber yield $\left(\mathrm{t} \mathrm{ha}^{-1}\right)$ in 3 potato trials in Ecuador with Fe and Zn fertilizer from 2012 to 2014

\begin{tabular}{|c|c|c|c|c|c|c|c|c|c|}
\hline \multirow[b]{2}{*}{ Source } & \multicolumn{3}{|c|}{ Trial 1} & \multicolumn{3}{|c|}{ Trial 2} & \multicolumn{3}{|c|}{ Trial 3} \\
\hline & df & MS & $P>F$ & $\mathrm{df}$ & MS & $P>F$ & $\mathrm{df}$ & MS & $P>F$ \\
\hline Total & 113 & & & 117 & & & 116 & & \\
\hline Block & 3 & 339.14 & $<0.0001$ & 3 & 18.68 & 0.042 & 3 & 13.96 & 0.6306 \\
\hline Cultivar (V) & 4 & 1710.1 & $<0.0001$ & 4 & 307.2 & $<0.0001$ & 4 & 560.11 & $<0.0001$ \\
\hline Main plot error & 11 & 64.87 & 0.0007 & 12 & 9.78 & 0.142 & 12 & 59.73 & 0.009 \\
\hline Fertilization $(\mathrm{F})$ & 5 & 28.34 & 0.197 & 5 & 10.3 & 0.175 & 5 & 30.19 & 0.2938 \\
\hline $\mathrm{V} \times \mathrm{F}$ & 20 & 24.93 & 0.1899 & 20 & 10.25 & 0.082 & 20 & 24.58 & 0.4513 \\
\hline Sub-plot error & 70 & 18.74 & & 73 & 6.49 & & 72 & 24.1 & \\
\hline
\end{tabular}

(Table 10). In the other trials no significant effect of $\mathrm{Zn}$ rates was detected on tuber yield (Table 11), or on plant emergence or plant height (data not shown). At the Pusniag site, the Tukey ranking $(P<0.05)$ indicated a significant increase of the tuber yield between the control and the lowest foliar $\mathrm{Zn}$ rate $(0.02 \% \mathrm{Zn})$, and no significant difference in tuber yield among the different $\mathrm{Zn}$ rates (Table 11). The mean tuber yields of cultivar INIAP-Natividad at the Cortijo bajo site were more than three times higher than at the Pusniag site, located at a higher altitude. Combined ANOVAs across sites revealed a highly significant effect of site on tuber yield
$(P<0.0001$, foliar application; $P<0.0001$, soil application). Interestingly, no negative effects on yield of the high $\mathrm{Zn}$ applications were seen with the edaphic conditions and fertilizer types of this study (Table 11).

A highly significant effect of $\mathrm{Zn}$ fertilizer rate was seen on tuber $\mathrm{Zn}$ concentration in all trials (Table 12). Both foliar and soil applied Zn significantly increased tuber $\mathrm{Zn}$ concentrations in cultivar INIAP-Natividad (Table 13). The highest foliar $\mathrm{Zn}$ rate increased the $\mathrm{Zn}$ concentration in tuber flesh 2.51-fold, and the highest soil $\mathrm{Zn}$ rate 1.91-fold (Table 13). Zinc concentration in haulms and roots was also significantly increased in all 4

Table 6 Mean iron and zinc concentration in peeled tubers of 5 Andean potato cultivars, and of 6 Fe and Zn fertilizer treatments in 3 field trials in Ecuador from 2012 to 2014

\begin{tabular}{|c|c|c|c|c|c|c|}
\hline & \multicolumn{3}{|c|}{ Tuber iron (mg kg ${ }^{-1}$ dry weight) } & \multicolumn{3}{|c|}{ Tuber zinc (mg kg ${ }^{-1}$ dry weight) } \\
\hline & Trial 1 & Trial 2 & Trial 3 & Trial 1 & Trial 2 & Trial 3 \\
\hline \multicolumn{7}{|l|}{ Cultivar } \\
\hline Chaucha roja & $25.57 \mathrm{a}$ & $70.03 \mathrm{ab}$ & $33.25 \mathrm{~b}$ & $17.26 \mathrm{a}$ & $20.81 \mathrm{a}$ & $8.62 \mathrm{ab}$ \\
\hline Chaucha amarilla & $26.00 \mathrm{a}$ & $75.48 \mathrm{a}$ & $37.42 \mathrm{a}$ & $13.32 \mathrm{~b}$ & $16.44 \mathrm{~b}$ & $9.23 \mathrm{a}$ \\
\hline Coneja negra & $25.10 \mathrm{a}$ & $43.64 \mathrm{c}$ & $26.26 \mathrm{c}$ & $11.56 \mathrm{~b}$ & $13.49 \mathrm{~b}$ & $7.24 \mathrm{~b}$ \\
\hline INIAP-Natividad & $20.96 \mathrm{~b}$ & $65.60 \mathrm{~b}$ & $24.78 \mathrm{c}$ & $9.47 \mathrm{c}$ & $13.72 \mathrm{~b}$ & $3.46 \mathrm{c}$ \\
\hline INIAP-Puca shungo & $17.67 \mathrm{c}$ & $43.16 \mathrm{c}$ & $17.17 \mathrm{~d}$ & $7.88 \mathrm{c}$ & $15.49 \mathrm{~b}$ & $1.94 \mathrm{c}$ \\
\hline \multicolumn{7}{|l|}{ Fertilizer treatment } \\
\hline ZnFe soil & $23.84 \mathrm{a}$ & $63.62 \mathrm{a}$ & $27.89 \mathrm{ab}$ & $13.08 \mathrm{a}$ & $16.28 \mathrm{abc}$ & $8.64 \mathrm{a}$ \\
\hline Zn soil & $23.10 \mathrm{a}$ & $55.92 \mathrm{~b}$ & $26.77 \mathrm{ab}$ & $12.00 \mathrm{ab}$ & $18.63 \mathrm{a}$ & $7.13 \mathrm{ab}$ \\
\hline $\mathrm{Zn}$ foliar & $22.36 \mathrm{a}$ & $60.56 \mathrm{ab}$ & $28.45 \mathrm{ab}$ & $11.01 \mathrm{ab}$ & $18.00 \mathrm{ab}$ & $6.66 \mathrm{ab}$ \\
\hline Fe foliar & $23.20 \mathrm{a}$ & $57.89 \mathrm{ab}$ & $26.30 \mathrm{~b}$ & $11.62 \mathrm{ab}$ & $14.97 \mathrm{abc}$ & $5.48 \mathrm{bc}$ \\
\hline Fe soil & $23.90 \mathrm{a}$ & $60.18 \mathrm{ab}$ & $29.22 \mathrm{a}$ & $11.17 \mathrm{ab}$ & $14.20 \mathrm{bc}$ & $4.46 \mathrm{c}$ \\
\hline Control & $22.14 \mathrm{a}$ & $59.31 \mathrm{ab}$ & $28.03 \mathrm{ab}$ & $10.19 \mathrm{~b}$ & $13.84 \mathrm{c}$ & $4.22 \mathrm{c}$ \\
\hline Mean & 23.09 & 59.58 & 27.78 & 11.50 & 15.77 & 6.10 \\
\hline
\end{tabular}

Values in the same column followed by the same letter are not significantly different according to Tukey's test $(P<0.05)$ 
Table 7 Individual analysis of variance (ANOVA) for main plot effect cultivar and subplot effect fertilizer treatment (zinc and/or iron) on concentration of iron (Fe) in peeled tubers in 3 potato trials in Ecuador with Fe and Zn fertilizer from 2012 to 2014

\begin{tabular}{|c|c|c|c|c|c|c|c|c|c|}
\hline \multirow[b]{2}{*}{ Source } & \multicolumn{3}{|c|}{ Trial 1} & \multicolumn{3}{|c|}{ Trial 2} & \multicolumn{3}{|c|}{ Trial 3} \\
\hline & $\mathrm{df}$ & MS & $P>F$ & df & MS & $P>F$ & df & MS & $P>F$ \\
\hline Total & 100 & & & 118 & & & 117 & & \\
\hline Block & 3 & 1.36 & 0.7851 & 3 & 124.2 & 0.093 & 3 & 7.058 & 0.445 \\
\hline Cultivar (V) & 4 & 255.27 & $<0.0001$ & 4 & 5431 & $<0.0001$ & 4 & 1433.36 & $<0.0001$ \\
\hline Main plot error & 9 & 1.75 & 0.8982 & 12 & 160.6 & 0.003 & 12 & 33.42 & $<0.0001$ \\
\hline Fertilization $(\mathrm{F})$ & 5 & 10.37 & 0.0288 & 5 & 131.8 & 0.048 & 5 & 21.93 & 0.023 \\
\hline $\mathrm{V} \times \mathrm{F}$ & 20 & 3.65 & 0.5292 & 20 & 67.92 & 0.266 & 20 & 15.98 & 0.0148 \\
\hline Sub-plot error & 59 & 3.83 & & 74 & 55.84 & & 73 & 7.84 & \\
\hline
\end{tabular}

trials (ANOVA, $P$ value $<0.005$ for all comparisons) (Table 14). A maximum $\mathrm{Zn}$ application level for increasing tuber $\mathrm{Zn}$ concentration was not identified. The data did not approximate a distinguishable saturation range, but rather approximated linear responses (Table 13).

The residual $\mathrm{Zn}$ concentrations (mean \pm standard error, $\mathrm{mg} \mathrm{kg}^{-1}$ ) in the soil at harvest in the treatments with soil applied $\mathrm{Zn}$ were for Pusniag: control $=0.48 \pm 0.08$, Level $1=2.48 \pm 0.79$; Level $2=7.38 \pm 1.33$; Level $3=$ $6.10 \pm 1.70$; Level $4=4.28 \pm 0.49$; and Cortijo bajo: control $=2.3 \pm 0.07 ;$ Level $1=2.53 \pm 0.28 ;$ Level $2=$ $6.08 \pm 1.13$; Level $3=6.78 \pm 1.21$; Level $4=11.1 \pm$ 1.15. The residual $\mathrm{Zn}$ concentrations (mean \pm standard error, $\mathrm{mg} \mathrm{kg}^{-1}$ ) in the soil at harvest in the treatments with foliar applied $\mathrm{Zn}$ were for Pusniag: control $=0.38$ \pm 0.085 , Level $1=0.4 \pm 0.07$; Level $2=0.53 \pm 0.131$; Level $3=0.38 \pm 0.09$; Level $4=0.50 \pm 0.09$; and Cortijo bajo: control $=1.45 \pm 0.07$; Level $1=1.35 \pm$ 0.10 ; Level $2=1.18 \pm 0.18$; Level $3=2.13 \pm 0.13$; Level $4=2.30 \pm 0.07$.

\section{Discussion}

This study showed that simple fertilizer practices enhancing $\mathrm{Zn}$ supply to potato plants can increase the $\mathrm{Zn}$ concentration of potato tuber flesh and peel. The experiments showed a statistically significant effect of foliar and soil applied $\mathrm{Zn}$ fertilization on potato tuber $\mathrm{Zn}$ concentration. All $\mathrm{Zn}$ rates tested in the pot and field experiments resulted in relatively constant increases of tuber $\mathrm{Zn}$ with an increase in $\mathrm{Zn}$ fertilizer rate without affecting tuber yield negatively. Thus, the results confirmed a proof of concept that Andean potato cultivars can be agronomically $\mathrm{Zn}$-biofortified with $\mathrm{Zn}$ fertilizers, and future research should aim at determining a maximum limit to $\mathrm{Zn}$ fertilizer biofortification by taking into consideration further elevated rates of $\mathrm{Zn}$ application to the potato crop and determine economic optimum rates, which were not considered in our study.

The field trials with Fe and $\mathrm{Zn}$ fertilizers showed a significant effect of the $\mathrm{Zn}$ fertilizer treatments on tuber

Table 8 Individual analysis of variance (ANOVA) for main plot effect cultivar and subplot effect fertilizer treatment (zinc and/or iron) on concentration of zinc in peeled tubers in 3 potato trials in Ecuador with Fe and Zn fertilizer from 2012 to 2014

\begin{tabular}{|c|c|c|c|c|c|c|c|c|c|}
\hline \multirow[b]{2}{*}{ Source } & \multicolumn{3}{|c|}{ Trial 1} & \multicolumn{3}{|c|}{ Trial 2} & \multicolumn{3}{|c|}{ Trial 3} \\
\hline & d.f. & MS & $P>F$ & d.f. & MS & $P>F$ & d.f. & MS & $P>F$ \\
\hline Total & 108 & & & 113 & & & 119 & & \\
\hline Block & 3 & 1.81 & 0.7627 & 3 & 83.1 & 0.007 & 3 & 4.95 & 0.4491 \\
\hline Cultivar (V) & 4 & 255.56 & $<0.0001$ & 4 & 152.7 & $<0.0001$ & 4 & 250.39 & $<0.0001$ \\
\hline Main plot error & 11 & 11.16 & 0.0153 & 12 & 63.69 & 0.0007 & 12 & 10.01 & 0.0625 \\
\hline Fertilization $(\mathrm{F})$ & 5 & 21.37 & 0.0013 & 5 & 77.19 & 0.003 & 5 & 57.81 & $<0.0001$ \\
\hline $\mathrm{V} \times \mathrm{F}$ & 20 & 5.40 & 0.3255 & 20 & 26.72 & 0.148 & 20 & 9.26 & 0.0582 \\
\hline Sub-plot error & 65 & 4.69 & & 69 & 18.94 & & 75 & 5.54 & \\
\hline
\end{tabular}


Table 9 Mean extraction of iron and zinc $\left(\mathrm{g} \mathrm{ha}^{-1}\right)$ in peeled tubers of 5 Andean potato cultivars in 3 field trials in Ecuador from 2012 to 2014

\begin{tabular}{|c|c|c|c|c|c|c|}
\hline \multirow[t]{2}{*}{ Cultivar } & \multicolumn{3}{|c|}{ Tuber iron $\left(\mathrm{g} \mathrm{ha}^{-1}\right)$} & \multicolumn{3}{|c|}{ Tuber zinc $\left(\mathrm{g} \mathrm{ha}^{-1}\right)$} \\
\hline & Trial 1 & Trial 2 & Trial 3 & Trial 1 & Trial 2 & Trial 3 \\
\hline Chaucha roja & $127.40 \mathrm{~d}$ & $100.90 \mathrm{c}$ & $113.70 \mathrm{bc}$ & $88.51 \mathrm{ab}$ & $34.78 \mathrm{~b}$ & $28.62 \mathrm{~b}$ \\
\hline Chaucha amarilla & $151.91 \mathrm{~cd}$ & $157.30 \mathrm{~b}$ & $124.48 \mathrm{a}$ & $92.90 \mathrm{ab}$ & $33.55 \mathrm{~b}$ & $31.21 \mathrm{a}$ \\
\hline Coneja negra & $237.82 \mathrm{a}$ & $158.36 \mathrm{~b}$ & $102.08 \mathrm{c}$ & $100.71 \mathrm{a}$ & $48.44 \mathrm{ab}$ & $29.34 b$ \\
\hline INIAP-Natividad & $192.93 \mathrm{~b}$ & $246.66 \mathrm{a}$ & $119.51 \mathrm{~b}$ & $88.08 \mathrm{ab}$ & $55.31 \mathrm{a}$ & $17.74 \mathrm{bc}$ \\
\hline INIAP-Puca shungo & $175.21 \mathrm{bc}$ & $141.92 \mathrm{bc}$ & $98.70 \mathrm{~d}$ & $72.59 \mathrm{~b}$ & $50.28 \mathrm{ab}$ & $10.51 \mathrm{c}$ \\
\hline Mean & 177.05 & 161.03 & 111.69 & 88.56 & 44.47 & 23.48 \\
\hline
\end{tabular}

Values in the same column followed by the same letter are not significantly different according to Tukey's test $(P<0.05)$

Zn concentrations (Table 8); reaching about a 2-fold increase across cultivars (Table 6). The finding that potato can be Zn-biofortified with soil applied $\mathrm{Zn}$ stands apart from previous publications that have indicated that $\mathrm{Zn}$ biofortification of potato tubers may best be achieved with foliar $\mathrm{Zn}$ applications because of low phloem mobility of $\mathrm{Zn}$ and low functional xylem continuity to potato tubers from roots (Fontes et al. 1999; Rengel et al. 1999; Waters and Sankaran 2011; White et al. 2012; White and Broadley 2011). Soil chemical factors such as low $\mathrm{pH}$ in the Ecuadorian soils, and potato genotypic factors, may be some of the reasons for the good effectiveness of the soil $\mathrm{Zn}$ treatments in these experiments. To elucidate the efficacy of soil and foliar applied $\mathrm{Zn}$ rates a second set of field experiments was done. These experiments, conducted simultaneously at two sites in farmers' fields in the province of Chimborazo, resulted in a 2.51-fold tuber $\mathrm{Zn}$ increase from foliar $\mathrm{Zn}$ applications, and a 1.91-fold tuber $\mathrm{Zn}$ increase from soil $\mathrm{Zn}$ applications (Table 13). The tuber $\mathrm{Zn}$ increase from the foliar applications was, thus, slightly higher than the 2-fold increases found in studies with foliar applied $\mathrm{Zn}$ sulphate and $\mathrm{Zn}$ oxide in potato trials in Scotland (White et al. 2012), and considerably higher than the increases seen in a study done with $\mathrm{Zn}$ fertilizer with potato in Iran (Mousavi et al. 2007).

The highest tuber $\mathrm{Zn}$ and Fe concentrations were found in the diploid cultivars Chaucha roja and Chaucha amarilla (Table 6). The rankings of the cultivars according to the tuber concentrations of the two minerals were identical indicating a positive correlation between the genotypic concentrations of the two minerals, which was also found in previous work with native Andean potatoes in Peru (Burgos et al. 2007) and in other studies with potato (Carli and Khalikov 2008; Brown et al. 2010; Lefèvre et al. 2012). The ranking of the cultivars was maintained at all sites and following Fe and $\mathrm{Zn}$ fertilizer applications (Table 6). The rate of increase of tuber $\mathrm{Zn}$ following $\mathrm{Zn}$ fertilization was similar across cultivars. The diploid Chaucha cultivars that showed high tuber $\mathrm{Zn}$ concentrations in the absence of $\mathrm{Zn}$ fertilization also showed

Table 10 Mean tuber yields ( $\mathrm{tha}^{-1}$ ) of potato cultivar INIAP-Natividad in 4 potato trials with zinc fertilizer rates at 2 sites in the Ecuadorian Andes from 2013 to 2014

\begin{tabular}{|c|c|c|c|c|}
\hline \multirow[t]{2}{*}{ Zn rate } & \multicolumn{2}{|l|}{ Site: Pusniag } & \multicolumn{2}{|l|}{ Site: Cortijo bajo } \\
\hline & Foliar application & Soil application & Foliar application & Soil application \\
\hline Level 4 & $20.0 \mathrm{a}$ & $21.4 \mathrm{a}$ & $72.2 \mathrm{a}$ & $71.7 \mathrm{a}$ \\
\hline Level 3 & $18.2 \mathrm{ab}$ & $19.7 \mathrm{a}$ & $73.3 \mathrm{a}$ & $73.6 \mathrm{a}$ \\
\hline Level 2 & $18.1 \mathrm{ab}$ & $20.7 \mathrm{a}$ & $69.1 \mathrm{a}$ & $70.2 \mathrm{a}$ \\
\hline Level 1 & $19.9 \mathrm{a}$ & $20.6 \mathrm{a}$ & $67.4 \mathrm{a}$ & $66.9 \mathrm{a}$ \\
\hline Control & $16.7 \mathrm{~b}$ & $20.9 \mathrm{a}$ & $74.9 \mathrm{a}$ & $70.5 \mathrm{a}$ \\
\hline Mean & 18.6 & 20.7 & 71.4 & 70.6 \\
\hline
\end{tabular}

Values in the same column followed by the same letter are not significantly different according to Tukey's test $(P<0.05)$ 
Table 11 Individual analysis of variance (ANOVA) for $\mathrm{Zn}$ fertilizer effect, foliar or soil applications, on tuber yield ( $\mathrm{t}$ ha ${ }^{-1}$ ) of potato cultivar INIAP-Natividad in 4 potato trials at 2 sites in the Ecuadorian Andes from 2013 to 2014

\begin{tabular}{|c|c|c|c|c|c|c|c|c|c|}
\hline \multirow[b]{3}{*}{ Source } & \multirow[b]{3}{*}{ d.f. } & \multicolumn{4}{|c|}{ Site: Pusniag } & \multicolumn{4}{|c|}{ Site: Cortijo bajo } \\
\hline & & \multicolumn{2}{|c|}{ Foliar application } & \multicolumn{2}{|c|}{ Soil application } & \multicolumn{2}{|c|}{ Foliar application } & \multicolumn{2}{|c|}{ Soil application } \\
\hline & & MS & $P>F$ & MS & $\mathrm{P}>\mathrm{F}$ & MS & $\mathrm{P}>\mathrm{F}$ & MS & $P>F$ \\
\hline Total & 19 & & & & & & & & \\
\hline Block & 3 & 9.98 & 0.0060 & 7.62 & 0.3374 & 56.51 & 0.2493 & 4.89 & 0.9346 \\
\hline $\mathrm{Zn}$ rate & 4 & 7.77 & 0.0104 & 1.56 & 0.9009 & 37.53 & 0.4272 & 23.98 & 0.6172 \\
\hline Error & 12 & 1.45 & & 6.13 & & 36.13 & & 35.11 & \\
\hline
\end{tabular}

correspondingly higher tuber $\mathrm{Zn}$ concentration following foliar and soil applied Zn. Nevertheless, Zn soil uptake and translocation to haulms and tubers may vary significantly among cultivars. Many andigenum type cultivars have different root system architecture compared to tuberosum type cultivars (Iwama and Nishibe 1989; Wishart et al. 2013). The cultivar specific root system architecture of the Andean cultivars tested in this study, which could enhance functional xylem continuity to tubers from roots, could explain the successful $\mathrm{Zn}$ uptake from soil in this study compared to what could be expected in tuberosum type cultivars.

The soil $\mathrm{Zn}$ concentration between 1.3 and $3.7 \mathrm{mg} \mathrm{Zn}$ $\mathrm{kg}^{-1}$ (modified Olsen extract) at the sites used for this study only resulted to be a yield limiting factor in the trial with foliar applied $\mathrm{Zn}$ at the Pusniag site, the site with the lowest natural soil $\mathrm{Zn}$ concentration among our trials. At the other experimental sites the statistical analyses did not reveal significant effects of the $\mathrm{Zn}$ fertilization on plant production in terms of emergence, plant height or tuber yield (number and weight of tubers). In a similar study done recently in the Bolivian Andes, Gabriel et al. (2015) found a positive yield effect of soil
$\mathrm{Zn}$ fertilization (5 to $15 \mathrm{~kg} \mathrm{Zn} \mathrm{ha}^{-1}$ as $\mathrm{Zn}$ sulphate) in two native potato landrace cultivars. López et al. (2014) found significant yield gains in diploid potato through foliar applied EDTA-Zn chelate and soil applied Zn sulphate in Colombia. The high organic matter content and low $\mathrm{pH}$ causing high natural soil $\mathrm{Zn}$ availability in the soils in Ecuador could have been reasons why we did not detect a yield effect of the $\mathrm{Zn}$ treatments in all trials, but could also be caused by other unidentified confounding effects in the trials. A recent study done in the coastal area of Peru, in a high $\mathrm{pH}$ and calcareous soil, showed no effect of $\mathrm{Zn}$ sulphate applications $(11 \mathrm{~kg} \mathrm{Zn}$ $\mathrm{ha}^{-1}$ to soil plus two foliar $\mathrm{Zn}$ applications) on yield or tuber $\mathrm{Zn}$ concentration in Chilotanum Group cultivars (Delgado Otero 2015).

The field trials resulted in high haulm $\mathrm{Zn}$ concentrations in the trials with soil applied Zn (Table 13), which indicates that $\mathrm{Zn}$ is xylem mobile as it was readily translocated from potato roots to haulms. In the $\mathrm{Zn}$ sufficient control plants that had not received $\mathrm{Zn}$ fertilization, the $\mathrm{Zn}$ concentrations in haulms were in a range of 7 to 11 times higher than the $\mathrm{Zn}$ concentrations in peeled tubers (Tables 13 and 14). This implies that the

Table 12 Individual analysis of variance (ANOVA) for $\mathrm{Zn}$ fertilizer effect, foliar or soil application, on concentration of zinc in peeled tubers of potato cultivar INIAP-Natividad in 4 potato trials at 2 sites in the Ecuadorian Andes from 2013 to 2014

\begin{tabular}{|c|c|c|c|c|c|c|c|c|c|}
\hline \multirow[b]{3}{*}{ Source } & \multirow[b]{3}{*}{ d.f. } & \multicolumn{4}{|c|}{ Site: Pusniag } & \multicolumn{4}{|c|}{ Site: Cortijo bajo } \\
\hline & & \multicolumn{2}{|c|}{ Foliar application } & \multicolumn{2}{|c|}{ Soil application } & \multicolumn{2}{|c|}{ Foliar application } & \multicolumn{2}{|c|}{ Soil application } \\
\hline & & MS & $P>F$ & MS & $\mathrm{P}>\mathrm{F}$ & MS & $\mathrm{P}>\mathrm{F}$ & MS & $P>F$ \\
\hline Total & 19 & & & & & & & & \\
\hline Block & 3 & 0.46 & 0.9597 & 6.14 & 0.2377 & 0.10 & 0.7387 & 0.57 & 0.0010 \\
\hline $\mathrm{Zn}$ rate & 4 & 44.78 & 0.0011 & 44.16 & 0.0004 & 12.40 & $<0.0001$ & 5.46 & $<0.0001$ \\
\hline Error & 12 & 4.74 & & 3.80 & & 0.24 & & 0.05 & \\
\hline
\end{tabular}


Table 13 Mean zinc concentration ( $\mathrm{mg} \mathrm{Zn} \mathrm{kg}^{-1}$ dry weight) in flesh and skin of tubers of potato cultivar INIAP-Natividad as response to 5 foliar and 5 soil applied $\mathrm{Zn}$ fertilization rates in 4 potato trials at 2 sites in the Ecuadorian Andes in 2013 to 2014

\begin{tabular}{|c|c|c|c|c|c|c|c|c|}
\hline \multirow[t]{3}{*}{ Zn rate } & \multicolumn{4}{|c|}{ Site: Pusniag } & \multicolumn{4}{|c|}{ Site: Cortijo bajo } \\
\hline & \multicolumn{2}{|c|}{ Foliar application } & \multicolumn{2}{|c|}{ Soil application } & \multicolumn{2}{|c|}{ Foliar application } & \multicolumn{2}{|c|}{ Soil application } \\
\hline & Flesh & Skin & Flesh & Skin & Flesh & Skin & Flesh & Skin \\
\hline Level 4 & $15.20 \mathrm{a}$ & $28.95 \mathrm{a}$ & $17.60 \mathrm{a}$ & $38.60 \mathrm{a}$ & $9.28 \mathrm{a}$ & $16.90 \mathrm{a}$ & $7.53 \mathrm{a}$ & $16.90 \mathrm{a}$ \\
\hline Level 3 & $11.40 \mathrm{ab}$ & $24.65 \mathrm{ab}$ & $16.45 \mathrm{ab}$ & $29.92 \mathrm{~b}$ & $7.78 \mathrm{~b}$ & $15.68 \mathrm{ab}$ & $6.68 \mathrm{~b}$ & $14.20 \mathrm{ab}$ \\
\hline Level 2 & $11.10 \mathrm{ab}$ & $22.70 \mathrm{abc}$ & $15.13 \mathrm{ab}$ & $26.70 \mathrm{bc}$ & $7.27 \mathrm{~b}$ & $13.10 \mathrm{bc}$ & $6.10 \mathrm{c}$ & $13.20 \mathrm{ab}$ \\
\hline Level 1 & $9.18 \mathrm{bc}$ & $20.40 \mathrm{bc}$ & $12.90 \mathrm{bc}$ & $25.25 \mathrm{bc}$ & $6.82 \mathrm{~b}$ & $12.15 \mathrm{~cd}$ & $5.50 \mathrm{~d}$ & $11.60 \mathrm{~b}$ \\
\hline Control & $6.05 \mathrm{c}$ & $15.85 \mathrm{c}$ & $9.20 \mathrm{c}$ & $19.82 \mathrm{c}$ & $4.43 \mathrm{c}$ & $9.60 \mathrm{~d}$ & $4.45 \mathrm{e}$ & $10.70 \mathrm{~b}$ \\
\hline
\end{tabular}

Values in the same column followed by the same letter are not significantly different according to Tukey's test $(P<0.05)$

sink strength of potato haulms is approximately ten-fold higher than that of potato tuber flesh, which is linked to the different functional tissues in the plant organs, but also to low phloem mobility of $\mathrm{Zn}$ (White and Broadley 2011; White et al. 2012). The upper limit to agronomic $\mathrm{Zn}$ biofortification of potato tubers may, therefore, not lie far from the 2.5-fold magnitude found in this study, which corroborates the results of a previous study by White et al. (2012). The interpretation of haulm $\mathrm{Zn}$ concentrations of plants that had received foliar $\mathrm{Zn}$ sprays should be done with care, as the reported concentrations (Table 14) may have included $\mathrm{Zn}$ deposited on foliage that had not passed the plant cuticle despite careful rinsing of haulms prior to analysis.

The study did not produce proof-of-concept results that fertilization with $\mathrm{Fe}$ fertilizers can increase Fe concentrations in Andean potatoes. The greenhouse pot experiments showed no positive correlation between Fe fertilization and Fe concentration in tubers (Fig. 1). The
Fe concentration in peeled tubers of cultivar INIAPNatividad was significantly reduced and not increased when adding foliar applied $\mathrm{Fe}$ to the soil applied $\mathrm{Fe}$. Indeed, the majority of the plants in the pot experiments that received foliar Fe showed $\mathrm{Fe}$ toxicity symptoms on leaves in both cultivars. It is possible that the unsuccessful effect of the Fe foliar applications was related to the Fe-EDTA compound used, which may have penetrated poorly through the leaf surface, because of low humidity in the greenhouse and high points of deliquescence known of chelates (Schönherr et al. 2005). The Fe treatments in the field experiments, likewise, did not increase Fe concentration in tubers (Table 6). The high rate of FeEDTA used in these experiments may not have been the optimal foliar Fe application method. Future work should explore alternative foliar application methods, e.g. with the use of an appropriate surfactant and Fe sulphate, which has resulted in successful root translocation in tomato, another Solanaceae (Carrasco-Gil et al. 2016).

Table 14 Mean zinc concentration ( $\mathrm{mg} \mathrm{Zn} \mathrm{kg}^{-1}$ dry weight) in roots and haulms of potato cultivar INIAP-Natividad as response to 5 foliar and 5 soil applied $\mathrm{Zn}$ fertilization rates in 4 potato trials at 2 sites in the Ecuadorian Andes in 2013 to 2014

\begin{tabular}{|c|c|c|c|c|c|c|c|c|}
\hline \multirow[t]{3}{*}{$\mathrm{Zn}$ rate } & \multicolumn{4}{|c|}{ Site: Pusniag } & \multicolumn{4}{|c|}{ Site: Cortijo bajo } \\
\hline & \multicolumn{2}{|c|}{ Foliar application } & \multicolumn{2}{|c|}{ Soil application } & \multicolumn{2}{|c|}{ Foliar application } & \multicolumn{2}{|c|}{ Soil application } \\
\hline & Roots & Haulms & Roots & Haulms & Roots & Haulms & Roots & Haulms \\
\hline Level 4 & $109.80 \mathrm{a}$ & $163.85 \mathrm{a}$ & $664.05 \mathrm{a}$ & $242.50 \mathrm{a}$ & $73.85 \mathrm{a}$ & $71.38 \mathrm{a}$ & $117.82 \mathrm{a}$ & $76.15 \mathrm{a}$ \\
\hline Level 3 & $88.13 \mathrm{a}$ & $129.50 \mathrm{ab}$ & $458.40 \mathrm{~b}$ & $195.97 \mathrm{ab}$ & $67.38 \mathrm{a}$ & $62.95 \mathrm{ab}$ & $92.15 \mathrm{ab}$ & $66.40 \mathrm{ab}$ \\
\hline Level 2 & $85.42 \mathrm{a}$ & $105.90 \mathrm{bc}$ & $417.35 \mathrm{~b}$ & $177.18 \mathrm{ab}$ & $65.15 \mathrm{a}$ & $59.28 \mathrm{abc}$ & $87.58 \mathrm{ab}$ & $62.35 \mathrm{~b}$ \\
\hline Level 1 & $58.43 \mathrm{~b}$ & $99.28 \mathrm{bc}$ & $230.63 \mathrm{c}$ & $140.20 \mathrm{bc}$ & $55.75 \mathrm{ab}$ & $53.10 \mathrm{bc}$ & $79.48 \mathrm{~b}$ & $57.65 \mathrm{bc}$ \\
\hline Control & $42.70 \mathrm{~b}$ & $76.58 \mathrm{c}$ & $70.40 \mathrm{~d}$ & $85.00 \mathrm{c}$ & $42.48 \mathrm{~b}$ & $45.50 \mathrm{c}$ & $60.52 \mathrm{~b}$ & $48.40 \mathrm{c}$ \\
\hline
\end{tabular}

Values in the same column followed by the same letter are not significantly different according to Tukey's test $(P<0.05)$ 
A recent study in Bolivia with two Andean potato cultivars receiving Fe sulphate (10 to $40 \mathrm{~kg} \mathrm{Fe} \mathrm{ha}^{-1}$ ) applied to the soil before planting also resulted in unsuccessful translocation of Fe to tubers (Gabriel et al. 2015). The fact that Fe applied to the rhizosphere is quickly converted into plant-unavailable $\mathrm{Fe}^{3+}$ forms, and the fact that Fe has low xylem mobility and translocation capacity in the potato plant limits the prospect of biofortifying potatoes with Fe fertilizer (Rengel et al. 1999; Rashid and Ryan 2004; White and Broadley 2011). Future studies should investigate which soil factors could eventually be managed to stabilize tuber $\mathrm{Fe}$ output across environments and ensure that a higher part of the total soil Fe becomes plant available and is taken up by roots, e.g., the usage of acidifying fertilizers, such as urea or ammonium fertilizers, or inoculating soils with mineral solubilizing microorganisms, such as $\mathrm{Zn}$ and Fe transporting arbuscular mycorrhizal fungi (Lehmann and Rillig 2015) or siderophore producing bacteria that make Fe plant available through chelation (Velivelli et al. 2014).

Zinc sulphate has been widely used to biofortify crops with Zn (White and Broadley 2011; Velu et al. 2014) and also as foliar applications in potato (White et al. 2012). Chelates have also been used although to a lesser extent because of their higher price. Chelates generally offer a nutrient use efficiency up to 5 times higher than that of inorganic salts, but the price is also 5 to 10 times higher (Alloway 2008). The various forms of $\mathrm{Zn}$ and $\mathrm{Fe}$ fertilizer and ways of applying to the potato crop may influence the efficiency of uptake and translocation to tubers differently. In our trials we used amino acid based and chelated $\mathrm{Zn}$ and Fe fertilizers because they were commonly used and readily available in Ecuador, to avoid an effect from the sulfur in sulphates, and with the objective to study fertilizer forms more likely to be taken up and translocated to tubers. The rates used were about 2 to 5 times higher than the manufacturers' recommendations for adjusting mineral concentrations for optimal potato production and considerably higher than rates used in common practical agriculture. Although a concomitant negative effect of Fe application on yield was seen, no negative effect of foliar $\mathrm{Zn}$ applications were seen in this study, in contrast to the negative potato yield effects indicated in previous studies when applying high rates of $\mathrm{ZnSO}_{4}$ or $\mathrm{ZnO}$ to Chilotanum Group cultivars (White et al. 2012; Delgado Otero 2015). For practical recommendations on agronomic biofortification of potato with $\mathrm{Zn}$ additional studies are needed to define economic optimal compounds, application methods and rates. Furthermore, care should be taken to avoid significant and potentially toxic increases in total soil zinc concentrations following continuous application of high soil $\mathrm{Zn}$ rates (20 to $40 \mathrm{~kg} \mathrm{ha}^{-1}$ ). The residual value of such high applications may serve for more than the normal recommended potato rotation period of 4 years.

The field trials were conducted under varying growing conditions and soils, and a strong site effect on tuber mineral concentrations, associated in part to tuber yields, was evident among trials. The variation among trial sites and planting dates serves to represent some of the large variation found among potato growing environments in the Ecuadorian Andes, where potato is grown year-round, and not uncommonly in soil and altitudes above 3500 m.a.s.l. The largest variation in Fe concentration in peeled tubers was seen in cultivar INIAP-Natividad between Trial 1 and 2 with a 3 -fold difference in $\mathrm{Fe}$ concentration (Table 6). The largest variation in $\mathrm{Zn}$ concentration in peeled tubers was seen in cultivar INIAP-Puca shungo between Trial 2 and 3 with a 8 -fold difference caused by the very low tuber $\mathrm{Zn}$ concentration in Trial 3 (1.94 $\mathrm{mg} \mathrm{kg}^{-1} \mathrm{dw}$ ) (Table 6). Previous studies have shown similar strong site effects on tuber mineral concentrations (Burgos et al. 2007; Brown et al. 2010; Haynes et al. 2012; Nassar et al. 2012). Burgos et al. (2007) reported a variation in tuber Fe concentration in the 3-fold range among sites in Peru, whereas Brown et al. (2010) reported a 4-fold difference in Fe tuber concentrations among sites in the United States. It is noteworthy that the sites in our trials resulting in the lowest tuber $\mathrm{Zn}$ concentrations, Tunshi and Cortijo Bajo, were sites with high soil calcium concentrations and relatively high $\mathrm{pH}$.

The $\mathrm{Fe}$ and $\mathrm{Zn}$ concentration in tubers was strongly associated with tuber yield. In the field trials with $\mathrm{Fe}$ and $\mathrm{Zn}$ fertilizer, the Pearson correlation coefficients between tuber mineral concentrations and yield were all negative and highly significant. Tuber bulking and increased yield diluted $\mathrm{Zn}$ and $\mathrm{Fe}$ in tuber tissue in agreement with previous studies (Kolbe and Stefan-Beckmann 1997; White et al. 2009). Environmental and genetic factors that affect tuber size are, therefore, important to consider in any potato biofortification effort.

Interestingly, the accumulation of $\mathrm{Zn}$ in tubers appeared to be affected by other site effects than the yield factor affecting mineral concentrations in tubers negatively. In the field trials with Fe and $\mathrm{Zn}$ fertilizer, tuber 
yield was highest in Trial 1 and tuber $\mathrm{Zn}$ was lowest in Trial 3. The zinc extraction taken by tubers was, thus, lowest in Trial 3 (Table 9). The low tuber $\mathrm{Zn}$ concentrations found in this trial in both soil and foliar applied $\mathrm{Zn}$ treatments may have been related to a number of factors affecting the $\mathrm{Zn}$ mobility in the plants; the high soil $\mathrm{pH}$, the high natural soil $\mathrm{Ca}$ concentration (Miyasaka and Grunes 1997; Alloway 2008; Iratkar et al. 2014), enhanced P availability (Alloway 2008; Yang et al. 2011) and low organic matter content at this site (Iratkar et al. 2014), but could also be related to the use of calcium nitrate fertilizer instead of ammonium nitrate or the intensive gravity irrigation used in this trial that could have affected the root systems and the plants' capacity to capture soil nutrients (Opena and Porter 1999; Lahlou and Ledent 2005) or even caused increased leaching of the applied soil fertilizer.

Taking into account the low soil $\mathrm{Zn}$ level in Andean soils (Beek and Bramao 1968; Alloway 2008) that appear to be a major factor causing low human $\mathrm{Zn}$ intake, agronomic $\mathrm{Zn}$ biofortification of potato may prove to be an important approach to improve the critical human $\mathrm{Zn}$ status in the Andes. The International Potato Center currently has more than fifty genetically biofortified potato clones with the capacity to absorb and contain more than $35 \mathrm{mg} \mathrm{Zn}$ and $35 \mathrm{mg} \mathrm{Fe} \mathrm{kg}{ }^{-1}$ tuber flesh dw. A strategy of combined approaches supporting the synergy between genetic and agronomic biofortification could ensure a wider value of both approaches. Future research should aim at determining economic optimum $\mathrm{Zn}$ rates, $\mathrm{Zn}$ fertilizer types and application methods, e.g. in combination with fungicide sprays to reduce the cost of application, considering significant residual effects from soil applications and the potential high synergy between $\mathrm{Zn}$ accumulating cultivars and $\mathrm{Zn}$ applications. Systematic surveys and mapping of plant available soil $\mathrm{Zn}$ concentrations across the Andes and other areas with apparent low soil Zn levels would aid the identification of areas with high potential for impact from $\mathrm{Zn}$ biofortification.

\section{Conclusion}

The results confirmed the proof of concept that Andean potato cultivars can be agronomically Zn-biofortified with foliar and soil applied Zn fertilizers. High rates of foliar $\mathrm{Zn}$ application reached a 2.51-fold tuber $\mathrm{Zn}$ increase, and high rates of soil $\mathrm{Zn}$ application a 1.91-fold tuber $\mathrm{Zn}$ increase in the field trials. A maximum $\mathrm{Zn}$ application level for increasing tuber $\mathrm{Zn}$ concentration was not identified, and a concomitant negative effect of high $\mathrm{Zn}$ applications on tuber yield or plant growth was not seen with the edaphic conditions, fertilizer types and cultivars of this study. Tuber Fe concentrations of Andean potatoes were not increased with Fe fertilization. The $\mathrm{Fe}$ and $\mathrm{Zn}$ concentrations in tubers were negatively correlated with tuber yield. The study showed a clear Znbiofortification effect across environments, but also a strong effect of site on the concentration of $\mathrm{Zn}$ in tubers that was not related to the dilution effect caused by increased yield, but more likely related to the chemical composition and physical characteristics of the soils. This research shows that application of $\mathrm{Zn}$ fertilizers or $\mathrm{Zn}$ enriched NPK fertilizers offer a prompt solution to increasing the $\mathrm{Zn}$ concentration in Andean potato tubers, and represents a useful complementary approach to ongoing breeding programs. However, care should be taken to avoid significant and potentially toxic increases in total zinc concentrations of soils following continuous application of high soil $\mathrm{Zn}$ rates. High levels of $\mathrm{Zn}$ in potato tubers may significantly improve the diets of $\mathrm{Zn}$-deficient populations with high intake of potato and contribute to better nutrition. Considering a daily consumption of 400 to $800 \mathrm{~g}$ of unpeeled potato per day in rural populations of the Andes, a strategy combining synergies between genetic and agronomic biofortification could cover between 30 and $75 \%$ of the estimated average adult requirements for $\mathrm{Fe}$ and $\mathrm{Zn}$. A governmental policy plan for $\mathrm{Zn}$ fertilization in potato appears to be a reasonable alternative for the Andean countries to reduce their high human $\mathrm{Zn}$ deficiency rates.

Acknowledgments This study was financed by the European Union (EU) through the project "Innovation for Food Security and Food Sovereignty in the Andes (IssAndes)". We thank Lilian Gavilánez for her thesis work, Rafael Parra and all the personnel at INIAP's Laboratory for Management of Soils and Water at the Santa Catalina Experiment station for their support with the analytical work and implementation of experiments, and María Gutiérrez (Pusniag) and Olmedo Caguana (Cortijo Bajo) for the use of their fields.

Open Access This article is distributed under the terms of the Creative Commons Attribution 4.0 International License (http:// creativecommons.org/licenses/by/4.0/), which permits unrestricted use, distribution, and reproduction in any medium, provided you give appropriate credit to the original author(s) and the source, provide a link to the Creative Commons license, and indicate if changes were made. 


\section{References}

Aciksoz SB, Yazici A, Ozturk L, Cakmak I (2011) Biofortification of wheat with iron through soil and foliar application of nitrogen and iron fertilizers. Plant Soil 349:215-225

Alloway BJ (2008) Zinc in soils and crop nutrition. Second edition, published by International Zinc Association (IZA), Brussels, Belgium and International Fertilizer Industry Association (IFA) Paris, France

Andre CM, Ghislain M, Bertin P, Oufir M, Del Rosario Herrera M, Hoffmann L, Hausman J, Larondelle Y, Evers D (2007) Andean potato cultivars (Solanum tuberosum L.) as a source of antioxidant and mineral micronutrients. J Agric Food Chem 55:366-378

Andre CM, Evers D, Ziebel J, Guignard C, Hausman J, Bonierbale M, Zum Felde T, Burgos G (2015) In vitro bioaccessibility and bioavailability of iron from potatoes with varying vita$\min \mathrm{C}$, carotenoid, and phenolic concentrations. J Agric Food Chem 63:9012-9021

Anonymous (2003) Encuesta nacional de consumo de alimentos en niños de 12 a 35 meses y mujeres en edad fértil. Centro Nacional de Alimentación y Nutrición. Instituto Nacional de Salud, Perú

Beek JK, Bramao DL (1968) Nature and geography of South American soils. In: Fittau EJ et al (eds) Biogeography and ecology in South America. Dr W Junk NV, Publishers, The Hague, pp 82-112

Bhan MK, Sommerfelt H, Strand T (2001) Micronutrient deficiency in children. Br J Nutr 85:S199-S203

Brown CR, Haynes KG, Moore M, Pavek MJ, Hane DC, Love SL, Novy RG, Miller J Jr (2010) Stability and broad-sense heritability of mineral content in potato: iron. Am J Potato Res 87:390-396

Burgos G, Amoros W, Morote M, Stangoulis J, Bonierbale M (2007) Iron and zinc concentration of native Andean potato cultivars from a human nutrition perspective. J Sci Food Agric 87:668-675

Burgos G, Salas E, Amoros W, Auqui M, Muñoa L, Kimura M, Bonierbale M (2009) Total and individual carotenoid profiles in Solanum phureja of cultivated potatoes: I. Concentrations and relationships as determined by spectrophotometry and HPLC. J Food Compos Anal 22:503-508

Cakmak I (2008) Enrichment of cereal grains with zinc: agronomic or genetic biofortification? Plant Soil 302:1-17

Cakmak I (2009) Enrichment of fertilizers with zinc: an excellent investment for humanity and crop production in India. J Trace Elem Med Biol 23:281-289

Cakmak I, Kalayci M, Kaya Y, Torun AA, Aydin N, Wang Y, Arisoy Z, Erdem H, Yazici A, Gokmen O, Ozturk L, Horst WJ (2010) Biofortification and localization of zinc in wheat grain. J Agric Food Chem 58:9092-9102

Carli C, Khalikov D (2008) Micronutrient composition of predominant potato (Solanum tuberosum L.) varieties cultivated in Uzbekistan. Potato J 35:41-45

Carrasco-Gil S, Rios JJ, Álvarez-Fernández A, Abadía A, GarcíaMina JM, Abadía J (2016) Effects of individual and combined metal foliar fertilisers on iron- and manganese-deficient Solanum lycopersicum plants. Plant Soil 402:27-45

Delgado Otero L (2015) Fertilización con zinc en dos variedades de papa (Solanum tuberosum) en suelos de Costa y Sierra.
Dissertation, Universidad Nacional Agraria la Molina, Lima, Peru

Devaux A, Kromann P, Ortiz O (2014) Potatoes for sustainable global food security. Potato Res 57:185-199

Dolores-Maldonado G, Delgado-Perez D, Creed-Kanashiro H (2015) Estrategias empleadas por las madres durante el proceso de alimentación en niños de 6 a 24 meses de dos comunidades rurales de Lima, Perú. Rev Peru Med Exp Salud Publica 32:440-448

FAO (2009) International year of the potato 2008: new light on a hidden treasure. http://www.fao.org/potato-2008 /en/events/book.html. Accessed 8 Jan 2016

Fontes PCR, Moreira MA, Fontes RLF, Cardoso AA (1999) Effects of zinc fungicides and different zinc fertilizer application methods on soluble and total zinc in potato plant shoots. Commun Soil Sci Plant Anal 30:1847-1859

Freire WB, Ramírez MJ, Belmont P, Mendieta MJ, Silva MK, Romero N, Sáenz K, Pineiros P, Gómez LF, Monge R (2013) Resumen ejecutivo. Tomo I. Encuesta Nacional de Salud y Nutrición del Ecuador. ENSANUT-ECU 20112013. Ministerio de Salud Pública/Instituto Nacional de Estadistica y Censos. Quito, Ecuador

Frossard E, Bucher M, Mächler F, Mozafar A, Hurrell R (2000) Potential for increasing content and bioavailability of Fe, $\mathrm{Zn}$ and $\mathrm{Ca}$ in plants for human nutrition. J Sci Food Agric 80: 861-879

Gabriel J, Arce M, Angulo A, Botello R, Casazola JL, Velasco J, Veramendi S, Rodríguez F (2015) Agronomic biofortification in two native potato cultivars (Solanum tuberosum L.). Rev Latinoam de la Papa 19:1-17

Gibson RS (2012) A historical review of progress in the assessment of dietary zinc intake as an indicator of population zinc status. Adv Nutr 3:772-782

Graham RD, Bouis HE, Welch RM (2001) Addressing micronutrient malnutrition through enhancing the nutritional quality of staple foods: principles, perspectives and knowledge gaps. Adv Agron 70:77-142

Grandy G, Weisstaub G, López De Romaña D (2010) Deficiencia de hierro y zinc en niños. Rev Soc Boliviana de Pediatría 49: 25-31

Gupta UC (1991) Iron status of crops in Prince Edward Island and effect of soil $\mathrm{pH}$ on plant iron concentration. Can J Soil Sci 71:197-202

Haynes K, Yencho G, Clough M, Henninger M, Sterrett S (2012) Genetic variation for potato tuber micronutrient content and implications for biofortification of potatoes to reduce micronutrient malnutrition. Am J Potato Res 89:192-198

Iratkar AG, Giri JD, Kadam MM, Giri JN, Dabhade MB (2014) Distribution of DTPA extractable micronutrients and their relationship with soil properties in soil of Parsori watershed of Nagpur district of Maharashtra. Asia J Soil Sci 9:297-299

Iwama K, Nishibe S (1989) Comparison of root characters among cultivated potatoes (Solanum tuberosum) and their wild relatives. Jpn J Crop Sci 58:126-132

Jiang W, Struik PC, van Keulen H, Zhao M, Jin LN, Stomph TJ (2008) Does increased $\mathrm{Zn}$ uptake enhance grain $\mathrm{Zn}$ mass concentration in rice? Ann Appl Biol 153:135-147

Joy EJM, Stein AJ, Young SD, Ander EL, Watts MJ, Broadley MR (2015) Zinc-enriched fertilisers as a potential public health intervention in Africa. Plant Soil 389:1-24 
King JC (2011) Zinc: an essential but elusive nutrient. Am J Clin Nutr 94(suppl):679S-684S

Kolbe H, Stefan-Beckmann S (1997) Development, growth and chemical composition of the potato crop (Solanum tuberosum L.). II. Tuber and whole plant. Potato Res 40:135-153

Lahlou O, Ledent JF (2005) Root mass and depth, stolons and roots formed on stolons in four cultivars of potato under water stress. Eur J Agron 22:159-173

Lefèvre I, Ziebel J, Guignard C, Hausman J, Gutiérrez Rosales RO, Bonierbale M, Hoffmann L, Schafleitner R, Evers D (2012) Drought impacts mineral contents in Andean potato cultivars. J Agron Crop Sci 198:196-206

Lehmann A, Rillig MC (2015) Arbuscular mycorrhizal contribution to copper, manganese and iron nutrient concentration in crops - a meta-analysis. Soil Biol Biochem 81:147-158

López A, Gómez MI, Rodríguez LE (2014) Effect of edaphic and foliar applications of different doses of zinc on the yield of the Criolla Colombia cultivar. Agronomía Colombiana 32: 70-77

Malavolta E, Vitti GC, De Oliveira SA (1989) Avaliacao do estado nutricional das plantas. principios y aplicaciones. Associación brasileira para pesquisa da potassa e do fosfato. Piracicaba, Brazil

McCall KA, Huang C, Fierke CA (2000) Function and mechanism of zinc metalloenzymes. J Nutr 130(5S Suppl):1437S-1446S

McClung JP, Marchitelli LJ, Friedl KE, Young AJ (2006) Prevalence of iron deficiency and iron deficiency anemia among three populations of female military personnel in the US Army. J Am Coll Nutr 25:64-69

Miyasaka SC, Grunes DL (1997) Root zone temperature and calcium effects on phosphorus, sulphur and micronutrients in winter wheat forage. Agron J 89:742-748

Mousavi SR, Galavi M, Ahmadvand G (2007) Effect of zinc and manganese foliar application on yield, quality and enrichment on potato (Solanum tuberosum L.). Asian J Plant Sci 6: $1256-1260$

Nassar AMK, Sabally K, Kubow S, Leclerc YN, Donnelly DJ (2012) Some Canadian-grown potato cultivars contribute to a substantial content of essential dietary minerals. J Agric Food Chem 60:4688-4696

Nestel P, Bouis HE, Meenakshi JV, Pfeiffer W (2006) Biofortification of staple food crops. J Nutr 136:1064-1067

Opena GB, Porter GA (1999) Soil management and supplemental irrigation effects on potato: II. Root growth. Agron J 91:426431

Paget M, Amoros W, Salas E, Eyzaguirre R, Alspach P, Apiolaza L, Noble A, Bonierbale M (2014) Genetic evaluation of micronutrient traits in diploid potato from a base population of Andean Landrace Cultivars. Crop Sci 54:1949-1959

Phattarakul N, Rerkasem B, Li LJ, Wu LH, Zou CQ, Ram H, Sohu VS, Kang BS, Surek H, Kalayci M, Yazici A, Zhang FS, Cakmak I (2012) Biofortification of rice grain with zinc through zinc fertilization in different countries. Plant Soil 361:131-141

Puga AP, Prado RM, Mattiuz B, do Vale DW, Fonseca IM (2013) Chemical composition of corn and sorghum grains cultivated in oxisol with different application methods and doses of zinc. Cienc Invest Agraria 40:97-108
Rashid A, Ryan J (2004) Micronutrient constraints to crop production in soils with Mediterranean type characteristics: a review. J Plant Nutr 27:959-975

Rengel Z, Batten GD, Crowley DE (1999) Agronomic approaches for improving the micronutrient density in edible portions of field crops. Field Crop Res 60:27-40

Schönherr J, Fernández V, Schreiber L (2005) Rates of cuticular penetration of chelated $\mathrm{Fe}^{\mathrm{III}}$ : role of humidity, concentration, adjuvants, temperature, and type of chelate. J Agric Food Chem 53:4484 4492

Stein AJ (2010) Global impacts of human mineral malnutrition. Plant Soil 335:133-154

Velivelli SLS, Sessitsch A, Prestwich BD (2014) The role of microbial inoculants in integrated crop management systems. Potato Res 57:291-309

Velu G, Ortiz-Monasterio I, Cakmak I, Hao Y, Singh RP (2014) Biofortification strategies to increase grain zinc and iron concentrations in wheat. J Cereal Sci 59:365-372

Waters BM, Sankaran RP (2011) Moving micronutrients from the soil to the seeds: genes and physiological processes from a biofortification perspective. Plant Sci 180:562-574

White PJ, Broadley MR (2009) Biofortification of crops with seven mineral elements often lacking in 638 human dietsiron, zinc, copper, calcium, magnesium, selenium and iodine. New Phytol 182:49-84

White PJ, Broadley MR (2011) Physiological limits to zinc biofortification of edible crops. Front Plant Sci 2:1-11

White PJ, Bradshaw JE, Dale MFB, Ramsay G (2009) Relationship between yield and mineral concentrations in potato tubers. HortSci 44:6-11

White PJ, Broadley MR, Hammond JP, Ramsay G, Subramanian NK, Thompson J, Wright G (2012) Biofortification of potato tubers using foliar zinc-fertilisers. J Hortic Sci Biotechnol 87: 123-129

Wishart J, George TS, Brown LK, Ramsay G, Bradshaw JE, White PJ, Gregory PJ (2013) Measuring variation in potato roots in both field and glasshouse: the search for useful yield predictors and a simple screen for root traits. Plant Soil 368: 231-249

Yang X, Tian X, Lu X, Cao Y, Chen Z (2011) Impacts of phosphorus and zinc levels on phosphorus and zinc nutrition and phytic acid concentration in wheat (Triticum aestivum L.). J Sci Food Agric 91:2322-2328

Zasoski RJ, Burau RG (1977) A rapid nitric-perchloric acid digestion method for multielement tissue analysis. Commun Soil Sci Plant Anal 3:425-436

Zhang YQ, Sun YX, Ye YL, Karim MR, Xue YF, Yan P, Meng QF, Cui ZL, Cakmak I, Zhang FS, Zou CQ (2012) Zinc biofortification of wheat through fertilizer applications in different locations of China. Field Crop Res 125:1-7

Zou CQ, Zhang YQ, Rashid A, Ram H, Savasli E, Arisoy RZ, Ortiz-Monasterio I, Simunji S, Wang ZH, Sohu V, Hassan M, Kaya Y, Onder O, Lungu O, Yaqub Mujahid M, Joshi AK, Zelenskiy Y, Zhang FS, Cakmak I (2012) Biofortification of wheat with zinc through zinc fertilization in seven countries. Plant Soil 361:119-130 